\title{
25.09.2014 Tarihinde Erzin Ilıcalarda (Hatay) Meydana Gelen Sel ve Taşkının Oluşumunda Coğrafi Faktörlerin Değerlendirilmesi
}

\author{
Evaluation of The Geographical Factors in the Formation of Flashflood and Flood in Erzin \\ Ilicalar (Hatay) On September 25, 2014
}

Ergin CANPOLAT ${ }^{1} \oplus$, Yücel DİNÇ ${ }^{1}$, Çetin Furkan USUN ${ }^{1} \oplus$, Reşat GEÇEN ${ }^{1} \oplus$

${ }^{1}$ Hatay Mustafa Kemal Üniversitesi, Fen Edebiyat Fakültesi, Coğrafya Bölümü, Hatay, Türkiye

ORCID: E.C. 0000-0003-2123-3551; Y.D. 0000-0002-0492-4724; F.U. 0000-0002-5205-8752; R.G. 0000-0002-4144-6645

\section{ÖZ}

Bu çalışmada, Erzin İlçesi Başlamış Mahallesi sınırları içerisindeki llıcalar mevkiinde 25.09.2014 tarihinde meydana gelen sel felaketi incelenmiştir. Çalışmanın amacı; llıcalar selinin meydana gelmesinde etkili olan jeomorfolojik, klimatolojik-hidrografik, antropojenik faktörleri ortaya koymak, yanlış arazi kullanımının neden olduğu olumsuz etkileri açıklamak ve yaşanabilecek sel felaketlerine karşı çözüm önerileri geliştirmektir. Bu amaca yönelik olarak, litolojik birimler ile sel felaketi arasındaki ilişki incelenmiş, sahanın yükselti değerlerinden hareketle hipsometrik eğri grafiği oluşturulmuş, hava olaylarını açıklayabilmek için meteorolojik veriler ile NOAA'nın Hysplit modeli kullanılmıştır. Yağışın havza genelindeki durumunu değerlendirebilmek için Schreiber'in aylık yağış hesaplama formülünden yararlanılmış, yağış enterpolasyonu oluşturulmuştur. Hidrolojik analizler kapsamında akarsu yoğunluğu hesaplanmış, bitki örtüsündeki değişimlerin sel felaketi ile olan ilişkilerini değerlendirmek için NDVI analizi uygulanmıştır. Ayrıca, afetzedelere yarı yapılandırılmış görüşmeler uygulanarak sel felaketinin etkileri ortaya konulmuştur. 25.09.2014 tarihinde Erzin'de 4-5 saat süren şiddetli yağışa ek olarak, sahadaki eğimin fazla olması, suyun kısa sürede vadiye yönelmesine neden olmuştur. llıcalara yakın noktada oldukça daralan vadinin, moloz, ağaç gövde ve dalları ile dolması, burada doğal bir set oluşturarak göllenme meydana getirmiştir. Biriken suyun basıncı ile bu set yıkılmış, dere yatağında inşa edilmiş yapılar su altında kalmış, 5 kişi hayatını kaybetmiş, 14 konut ve 42 işyeri afetten olumsuz etkilenmiştir. Su baskınının bu olumsuz sonuçları, yerleşmelerin kuruluş yeri seçimlerinde coğrafi şartların iyi bir şekilde analiz edilmesi gerektiğini göstermiştir.

Anahtar kelimeler: Erzin, doğal afet, sel, taşkın

\section{ABSTRACT}

This study investigates the flood disaster that occurred on September 25, 2014 in llıcalar, located in the borders of Başlamış, a neighborhood of Erzin district. This study aims to reveal the geomorphological, climatological-hydrographic, and anthropological factors that are effective in the llıcalar flood occurrence. It also aims to illustrate the adverse effects of inefficient land use and develop solutions for potential flood disasters. Thus, the relationship between lithological units and flood disaster has been investigated. A hypsometric curve graph has been created using the field's elevation values, and the Hysplit model of NOAA has been used to explain weather events. Schreiber's monthly precipitation calculation formula has been used, and precipitation interpolation has been created to evaluate the situation of precipitation throughout the basin. Within the scope of hydrological analysis, stream densities have been calculated, and Normalized Difference Vegetation Index analysis has been applied to evaluate the relationship between vegetation and flood disaster changes. Besides, semi-structured interviews have been applied to the disaster victims, and the effects of the flood disaster have been revealed. In addition to the heavy rain that lasted for 4-5 hours in Erzin on September 25, 2014, the field's high slope values caused the water to divert to the valley in a short time. The valley, which is very narrow at the point close to Erzin, is filled with rubble, tree trunk, and branches created a natural embankment there, creating a pond. The pressure of the accumulated water destroyed this embankment. Thus, the structures built on the streambed were submerged, five people lost their lives, 14 residences, and 42 workplaces were adversely affected by the disaster. These negative results of the flood showed that the geographical conditions should be analyzed well to select the settlements' establishment places.

Keywords: Erzin, natural disaster, flashflood, flood

Başvuru/Submitted: 28.05.2020 • Revizyon Talebi/Revision Requested: 17.08.2020 • Son Revizyon/Last Revision Received: 09.09 .2020 • Kabul/Accepted: 30.09 .2020 - Online Yayın/Published Online: 07.12.2020

Sorumlu yazar/Corresponding author: Ergin CANPOLAT / ergincanpolat@gmail.com

Atıf/Citation: Canpolat, E., Dinc, Y., Usun, C. F., \& Gecen, R. (2020). 25.09.2014 tarihinde Erzin llıcalarda (Hatay) meydana gelen sel ve taşkının oluşumunda coğrafi faktörlerin değerlendirilmesi. Cografya Dergisi, 41, 129-146. https://doi.org/10.26650/JGEOG2020-0048 


\section{EXTENDED ABSTRACT}

This study investigates the flood disaster that occurred due to the sudden flooding on September 25, 2014 in the Ilicalar, located in the Başlamış neighborhood of Erzin district of Hatay. The study’s primary purpose is to reveal the geomorphological, climatologicalhydrographic, and anthropological factors that caused the flooding of Ilicalar and explain the adverse effects of inefficient land use. It also aims to determine the problems arising from the fact that the structure of the place and its geographical conditions are not considered in selecting the settlements' location with the example of Ilicalar.

In this study, a 1/100.000 scale geology map has been obtained from the General Directorate of Mineral Research and Exploration to explain the research area's lithological and tectonic features. The research area's geomorphological features have been explained with a 1/25.000 scale topography map obtained from the General Directorate of Map. Besides, ALOS PALSAR DEM (Digital Elevation Model) with $12.5 \mathrm{~m}$ resolution has been used to show the topography in more detail. These data have been converted to point elevation data (Raster to Point); thus, the pixel-based cumulative percentage of the field's elevation values, i.e., the hypsometric curve graph, has been produced.

Annual, daily, and hourly precipitation data provided by the General Directorate of Meteorology have been used to reveal the climatic features. In addition, NOAA National Oceanic and Atmospheric Department) HYSPLIT (The Hybrid Single Particle Langrangian Integrated Trajectory Model) model has been used. Schreiber's monthly precipitation calculation formula has also been used to calculate the situation of heavy rain. It started in the evening hours on September 24, 2014 and continued until the first hours of the morning on September 25, 2014, throughout the basin. For this process, using DEM data, a total of 9.939-point elevation data randomly selected within the research area's boundaries have been produced. The Inverse Distance Weighting interpolation method has been applied to the data obtained from the Erzin-Yeşilkent meteorology station.

The stream data in the Gökgöldere (Sarıçay) basin have been obtained using the Hydrology plugin in the Spatial Analyst Tools module of ArcMap 10.5 software using ALOS PALSAR DEM data. The research area's river density has been determined by using the total length data and basin area data of these streams. It has been revealed how anthropogenic factors triggered the flood disaster with the help of the observations made in the research area and the images taken with Unmanned Aerial Vehicles.

Since the forest cover had been heavily destroyed in the months/years before the flood disaster, it has been considered necessary to determine vegetation change over the years. The Normalized Difference Vegetation Index (NDVI) analysis has been applied for this purpose. Landsat 5 (August 15, 2005), Landsat 5(August 29, 2010) Landsat 8 (August 24, 2014) satellite images; Landsat 8 Band 5 (Near Infrared), and Band 4 (Red); Landsat 58 Band 4 (Near Infrared) and Band 3 (Red) data have been used for this index. NDVI is found by proportioning the difference and sum of near infrared and red bands. It significantly removes the different enlightenment characteristics and shadow effects caused by the sun and perspective (Sellers, 1985; Melesse ve Jordan, 2003; Holben ve Frasher, 1984; Schultz ve Engman, 2000; Sotomayor, 2002; Özdemir, 2007; Canpolat, 2014). At the last stage of this study, a semi-structured interview method has been conducted with the disaster witnesses to explain the effects of the flood disaster.

The following findings are obtained from this study: The amount of precipitation measured by General Directorate of Meteorology for Erzin on September 25, 2014 is $69.6 \mathrm{~mm}$. In addition to the sudden and downpour precipitation that lasted for 4-5 hours, the high slope values increased the water's mass heading toward the valley in a short time. The valley, which narrowed very close to the Ilicalar, was filled with rubble, tree trunk, and branches dragged by the Sarı Çay. Then, a natural embankment was formed. As a result of the increase in precipitation, this set was destroyed with water pressure accumulated. Thus, the structures built in the stream bed were submerged. As a result of the flood, five people died, 14 residences and 42 workplaces have been adversely affected. These negative results of the flood revealed that the geographical conditions should be analyzed well in the settlements' site selection. 


\section{GÍRIŞ}

Doğal afet, insana ait alt ve üst yapılara zarar verebilen, ekonomik faaliyetleri etkileyen, can kaybına, yaralanmaya, hastalığa, evsiz kalınmasına ve toplumların sosyal anlamda çöküntüye uğramasına neden olabilen olaylardır. Doğal afetlerin, ağaçların yıkılıp yanmasından, mevcut yerküre şekillerinin ve peyzajın önemli ölçüde değişmesine kadar uzanacak etkileri olabilmektedir (Crowards, 2000). Dünyanın kendi döngüsü içerisinde meydana gelen doğal olayların afet niteliğine dönüşmesi, ekonomik gelişme bağlamında süregelen insan faaliyetlerinin doğal denge üzerine yaptığı müdahalelerin bir sonucu olmaktadır (Onuşluel ve Harmancıoğlu, 2002). Doğal tehlikeleri olan sahaların incelenmesi ve risklerinin değerlendirilmesi gerekmektedir. Unutulmaması gereken bir nokta var ki o da şudur; doğal tehlikeler kaçınılmazdır ancak doğal afetler kaçınılmaz değildir (Abbott, 2008).

Türkiye, doğal afetlerin sık olarak yaşandığı ülkelerden biridir. Sel ve taşkınlar bu afetler içerisinde yol açtıkları kayıplar nedeniyle üst sıralardadır. Başbakanlık Afet ve Acil Durum Yönetimi Başkanlığının Doğa Kaynaklı Olay İstatistikleri verisine göre, Türkiye ve yakın çevresinde 1900-2019 yılları arasında en az 5 büyüklüğünde 1796 deprem kaydedilmiştir. 1950-2019 yılları arasında 23.286 heyelan-kaya düşmesi olayı kaydedilmiştir. Aynı dönemde 6833 sel ve taşkının yanı sıra 1610 çığ olayı kaydedilmiştir (AFAD, 2020).

Doğal afetlerden biri olan sel ve taşkınlar; jeolojik, jeomorfolojik, klimatolojik, hidrografik, toprak ve bitki örtüsü özellikleri gibi birbirinden farklı coğrafi faktörlerin doğrudan veya dolaylı etkileri neticesinde meydana gelmektedir. Diğer yandan insanın doğal ortam üzerindeki etkilerini açıklayan antropojenik faktörler de sel felaketinin boyutlarını ve niteliğini etkileyebilmektedir. Antropojenik faktörlerin sel ve taşkınlar üzerindeki etkileri, genellikle arazi kullanımdaki değişimler neticesinde meydana gelmektedir (Sunkar ve Tonbul, 2011). Nitekim yanlış arazi kullanımı ve yetersiz yağmur suyu drenaj sistemleri, önceden tahmin edilemeyen ani su baskınları risklerinin sürekli artmasına yol açmaktadır (Ergünay, 2007). Özellikle yerleşim yerlerindeki veya çevrelerindeki derelerin sslah edilememesi veya sslah edilmeye çalışılması nedeniyle akarsu akış kesitinin olması gerekenden dar hale getirilmesi su baskınlarına neden olmaktadır (Karakuyu, 2002; Bodur, 2018).
Türkiye'de sel ve taşkın olayları, gerek doğal faktörlerin etkisiyle gerekse insanın doğal çevreye yönelik yanlış müdahaleleri neticesinde sıklıkla yaşanmaktadır. Karadeniz bölgesi yerleşmeleri başta olmak üzere ülkemizin birçok yerleșim biriminde meydana gelen sel ve taşkınların neden olduğu çevresel sorunlar bilimsel çalışmalara konu olmaktadır. Son y1llarda, Samsun, Giresun, Trabzon, Artvin, Muş, Kahramanmaraş ve Antalya'nın sınırları içerisinde meydana gelen sel ve taşkınları inceleyen çalışmalar, söz konusu çalışmalardan sadece birkaçını oluşturmaktadır. (Dölek, 2013; Bahadır, 2014; Turoğlu vd, 2015; Avc1 ve Sunkar, 2015; Kadığlu vd, 2016; Yılmaz ve Kaya, 2018; Fural vd, 2019; Sarıgül ve Turoğlu, 2020).

Hatay ili, ülkemizde sel ve taşkınların sıklıkla yaşandığ 1 yerleşmeler arasında yer almaktadır. Son yarım asırda Amik Ovasında çok sayıda taşkın olayı meydana gelmiştir. 1950'li yıllarda Hacıpaşa, 1960'lı yıllarda Kaskeli, Aktaş ve Karasüleymanlı köyleri, 1970'li yıllarda Karadurmuşlu, Muratpaşa, Gölbaşı, Baldıran ve Kızılkaya köyleri, 1980’lerde Karacanlık köyü ve 2003 yılında ise Terzihüyük, Kurtuluş ve Atçana köyleri Amik ovası taşkınlarından doğrudan etkilenen yerleşmeler olmuştur. Amanos dağlarının doğu ve batı kesimlerindeki akarsu vadilerinin tabanında veya yamaçlarında kurulmuş olan yerleşmeler de sel ve taşkın olaylarına maruz kalmışlardır. Amanos Dağlarının doğu kesimlerinde 1952 yılında Hacılar ve Güvenç, 1969 yılında Dedemli ve Salmanuşağı köyleri sel felaketinden olumsuz etkilenmişlerdir. Hatay'ın il merkezi durumundaki Antakya'nın merkez mahallelerinde 1998, 2001 ve 2009 y1llarında meydana gelen sel ve taşkınlar da can ve mal kayıplarına neden olmuştur ${ }^{1}$.

Amanos dağlarının batı yamacında özellikle İskenderunErzin arasında kalan sahada yer alan bazı yerleșmeler sel felaketleri ile sık sık karşılaşmaktadır. 1960'lı yıllarda Çat, Sarıseki-Değirmendere ve Cırtıman köylerinde meydana gelen sel felaketleri, söz konusu yerleşmeleri olumsuz etkilemiş hatta bu yerleşmelerin yer değiştirmelerine neden olmuștur ${ }^{2}$. Diğer yandan Erzin'in Ilıcalar mevkiinde 31 Mayıs 2003 ve 24 Temmuz 2014 tarihlerinde taşkın olayı meydana gelmiş, bu olay neticesinde can ve mal kayıpları yaşanmıştır (Atasoy ve Korkmaz, 2015: 454). Belirtilen sahada 5 kişinin ölümüyle sonuçlanan, büyük zararlara yol açan ve yerleşmenin terk edilmesiyle sonuçlanan son sel ve taşkın felaketi ise 25 Eylül 2014 tarihinde meydana gelmiştir. Bu çalışmada, Hatay’ın Erzin

1 Cumhurbaşkanlığı Devlet Arşivleri Başkanlığı Cumhuriyet Arşivleri ve Hatay Valiliği İl Afet ve Acil Durum Müdürlüğü

2 Cumhurbaşkanlığı Devlet Arşivleri Başkanlığı Cumhuriyet Arşivleri 
ilçesine bağlı Başlamış Mahallesinin Ilıcalar mevkiinde 25.09.2014 günü ani su baskınına bağlı olarak meydana gelen ve can ve mal kayıplarına neden olan sel felaketi incelenmiştir. Başlamış Mahallesi Ilıcalar mevkiinin içerisinde yer aldığı Gökgöldere Havzası (Sarıçay), coğrafi olarak, Amanos Dağlarının batı yamacında Erzin Ovası kenarında 350 ile 1900 'm yükselti basamakları arasında yer almaktadır (Şekil 1). Havza yaklaşık $29 \mathrm{~km}^{2}$ alan kaplamaktadır.

\section{MATERYAL VE YÖNTEM}

Sel ve taşkınları hazırlayan bileşenlerin sayısı fazla olmakla beraber, bu bileşenler her yerde aynı etkiyi göstermemektedir. $\mathrm{Bu}$ çalışmada, araştırma sahasının litolojik ve tektonik özelliklerini açıklayabilmek için Maden Tetkik ve Arama (MTA) Genel Müdürlüğü’nden 1/100.000 ölçekli jeoloji haritası temin edilmiştir. Harita Genel Müdürlüğü'nden elde edilen 1/25.000 ölçekli topoğrafya haritası yardımıyla sahanın jeomorfolojik özellikleri açıklanmıştır. Yine topoğrafyanın daha detaylı bir şekilde gösterilebilmesi bakımından 12,5 m çözünürlüklü ALOS PALSAR DEM (Sayısal Yükselti Modeli) kullanılmıştır (Web 1, 2019). Bu veri, noktasal yükselti verisine (Raster to Point) dönüştürülerek sahadaki yükselti değerlerinin piksel bazlı kümülatif yüzdesi yani hipsometrik eğri grafiği üretilmiştir.
Klimatik özelliklerin ortaya konulabilmesi için Meteoroloji Genel Müdürlüğü'nden temin edilen yıllık, günlük ve saatlik yağış verilerinden yararlanılmıştır. Ayrıca NOAA (Ulusal Okyanus ve Atmosfer Dairesi)'nın HYSPLIT (The Hybrid Single Particle Langrangian Integrated Trajectory Model) modeli kullanılmıştır. Burada veri, meteorolojik veri arşivinden temin edilerek sistem çalıştırılmıştır. Hava kütlelerinin geliş yüksekliği olarak 500 m, 1000 m ve 1500 m kullanılmıştır. Bitki örtüsünün yoğun olduğu bölgede arazinin genel görünüm fotoğrafları için İnsansız Hava Aracı (İHA) kullanılmıştır. 24.09.2014 tarihinde akşam saatlerinde başlayan ve 25.09.2014 tarihinde sabahın ilk saatlerine kadar devam eden şiddetli yağışın havza geneline düşme durumunun hesaplanması için Schreiber'in aylık yağı̧̧ hesaplama formülünden $(\mathrm{Ph}=\mathrm{Po}+4,5 \mathrm{~h})$ yararlanılmıştır. $\mathrm{Bu}$ işlem için DEM verisi üzerinden, araştırma sahası sınırları içerisinde rastgele olmak koşuluyla yükselti verisi olan 9939 adet nokta üretilmiştir. Bu nokta verisi 150 m yükseltideki ErzinYeşilkent meteoroloji istasyonu referans alınarak IDW (Inverse Distance Weighting) enterpolasyon yöntemi kullanılmıştır.

Hidrolojik analizler kapsamında, akarsuların toplam uzunluk verisi ve havza alanı verisinden yararlanılarak sahadaki akarsu yoğunluğu tespit edilmiştir. Sahada yapılan gözlemler ve insansız hava araçları ile çekilmiş görüntüler yardımıyla antropojenik faktörlerin sel felaketini nasıl tetiklemiş olduğu ortaya konulmuştur. Sel felaketinden önceki aylarda/yıllarda orman
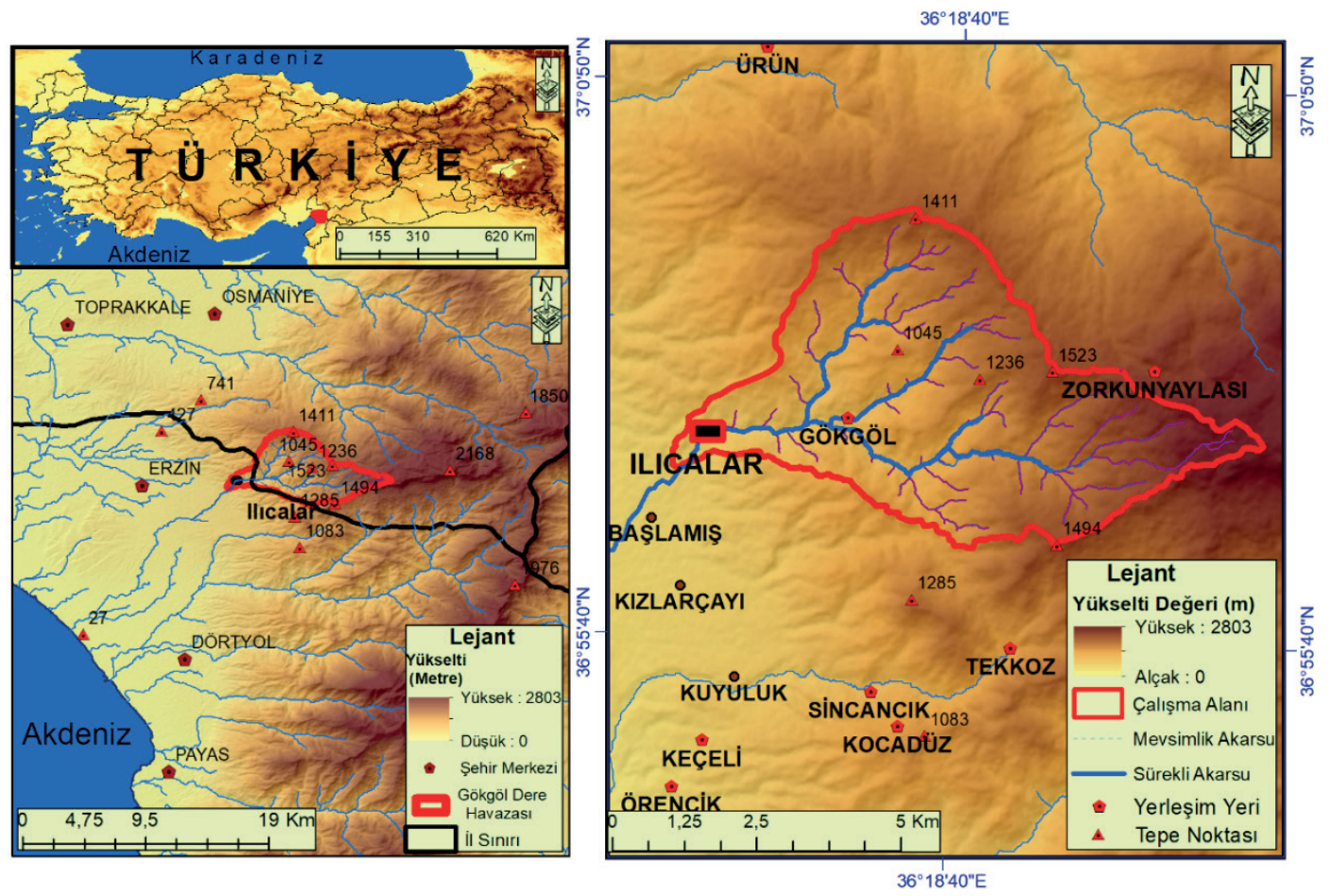

Şekil 1: Çalışma Alanının Lokasyon Haritası.

Figure 1: Location Map of the Study Area. 
örtüsünün yoğun bir şekilde tahrip edilmiş olması nedeniyle bitki örtüsünde yıllar içerisinde meydana gelen değişimin belirlenmesi gerekli görülmüştür. Bunun için NDVI (Normalized Difference Vegetation Index) analizi uygulanmıştır. $\mathrm{Bu}$ analizi gerçekleştirebilmek için Landsat 5 15.Ağu.2005, Landsat 5, 29. Ağu.2010, Landsat 8 24.Ağu.2014 uydu görüntülerinden Landsat 8 Band 5 (Near Infrared) ve Band 4 (Red); Landsat 58 Band 4 (Near Infrared) ve Band 3 (Red) verilerinden yararlanılmıştır. Son olarak sel felaketinin etkilerini somut bir şekilde açıklayabilmek için felaketin tanığı olan afetzedelerle yarı yapılandırılmış görüşme metodu gerçekleştirilmiştir. $\mathrm{Bu}$ görüşmelerden hareketle afetin neden olduğu can ve mal kayıplarına, sahadaki antropojenik etkilere, Ilıcalar'ın kaplıca turizmine bağlı yerleşme öyküsüne ve yerleşmenin terk edilme süreçlerine yönelik bilgiler elde edilmiştir.

\section{BULGULAR}

\subsection{JEOLOJIK-LITOLOJIK FAKTÖRLER}

Amanos Dağlarının batı eteğinde yer alan Ilıcalar yöresi, litolojik olarak Mesozoyik ultrabazik ofiyolitlerin, Jura-Kretase neritik kireçtaşlarının, Kuvaterner alüvyon ve yamaç molozlarının yer kapladığı bir sahadır. Havzada; en yaygın birim, Kızıldağ Ofiyoliti (Kk)'dır. Ofiyolitler çalışma sahasının 3/4'ne yakın bir bölümünü oluşturmaktadır (Şekil 2). Birim tabakalı gabro, izotrop gabro, levha dayk kompleksi ve volkanik kompleksten oluşur. Bunlar kalınlığı 10-40 cm arasında değişen piroksenit, aplit, granit aplit, ve yer yer de plajiyogranitler tarafindan kesilir. Tektonitler genelde harzburjit, dunit ve lerzolitten oluşur (Beyazpirinç ve Usta, 2018). Bu tip mafik ve

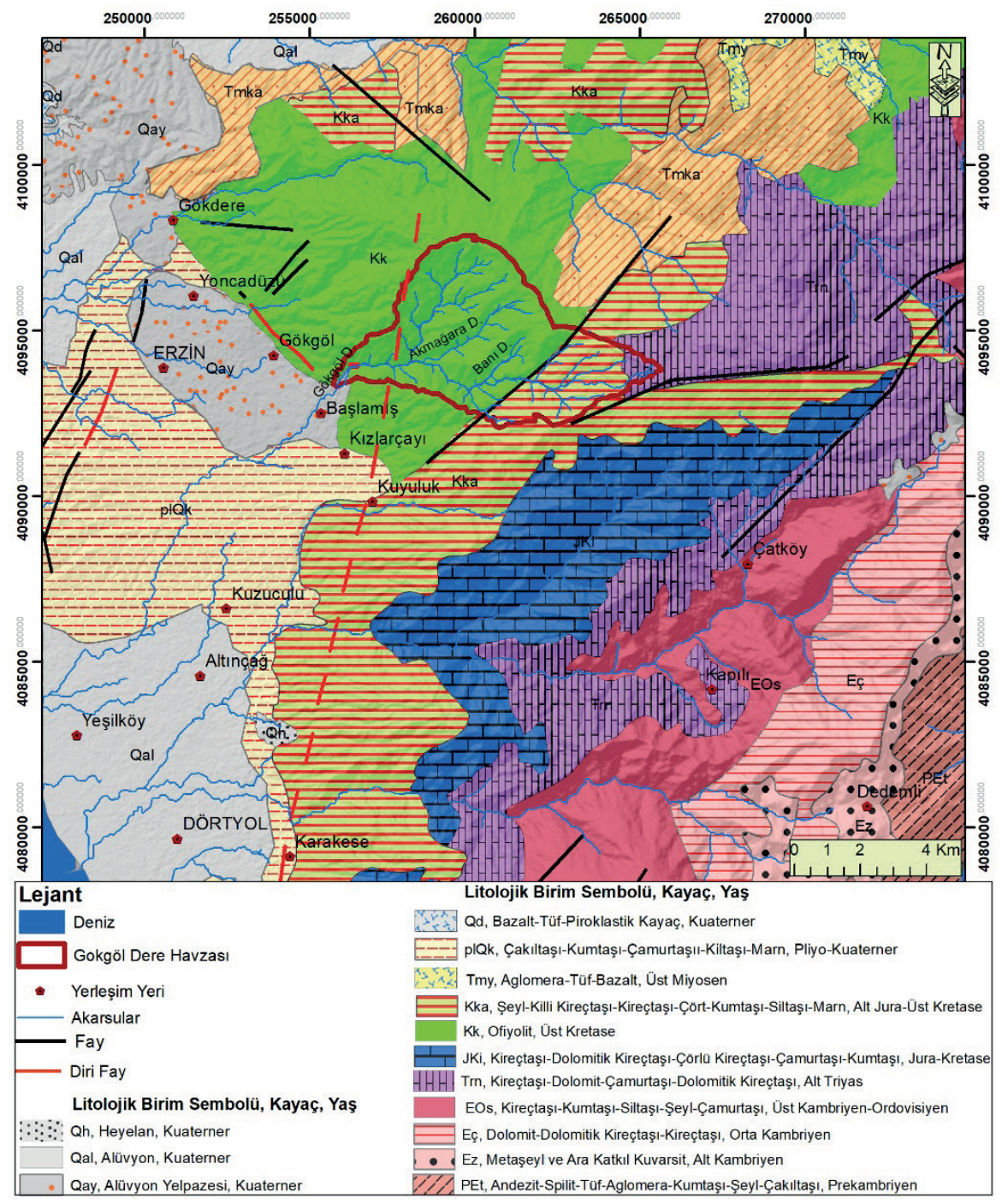

Şekil 2: Çalışma Alanının Jeoloji Haritası (Beyazpirinç ve Usta'nın hazırladığı MTA ,2018; 1/100.000 ölçekli Türkiye Jeoloji O-36 paftasına göre düzenlenmiştir).

Figure 2: Geological Map of the Study Area (Map reproduced from 1/100.000 Scaled Map Of Turkey Geological O-36 Map Sheet Which produced by MTA,2018). 
ultramafik kayaçlarda bol bulunan feldspat, olivin, piroksen, mika, plajiyoklas ve ortoklas kil üretimine uygun minerallerdir. Bundan dolayı alterasyon, yörede kil oluşumunu destekleyen bir süreçtir. Killerin topoğrafya yüzeyindeki varlığı ise özellikle yüzeysel akışı ve akarsu doğal yük miktarını etkileyen bir husustur (Karataş, 2019). Sahada yaygın kil oluşumu, geçirgenliği azaltmakta özellikle şiddetli yağışlarla düşen suyun hızla yüzeysel akışa geçmesine neden olmaktadır. Bu durum ise alterasyon ürünlerinin erozyonunda önemli rol oynamaktadır.

Karadut Formasyonu (Kka) sahanın doğu kesiminde yaygın bir formasyondur. Bu birim Erken Jura-Geç Kretase yaşlıdır. İnce-orta yer yer kalın tabakalı, açık gri, gri, koyu gri, yeşil, koyu yeşil, yeşilimsi gri, mavimsi gri, kahve, kırmızı, sarı renkli, silisli şeyl, şeyl, killi kireçtaşı, kireçtaşı ve çört ardalanmasından oluşur. Birimde mikritik dokulu ve çörtlü kireçtaşı yaygındır. Ayrıca yer yer çakıllı kireçtaşı, tübiditik çakılttaşı, silttaşı ve marn seviyeleri gözlenir. Çakıllı kireçtaş1; çört, mikritik kireçtaşı, ultrabazit, volkanik kayaç blokları ve fosil kavkı parçaları içerir. Sahanın doğusunda ise Nurdağı Formasyonu (Trn) olarak tanımlanan; Alt Triyas yaşlı, kireçtaşı-dolomit, dolomitik kireçtaşı, çamurtaşı birimleri görülmektedir (Beyazpirinç ve Usta, 2018).

Kıbrıs yayı ile Antakya-Maraş oluğu arasında yer alan Amanos Dağları, doğu ve batı kesiminde faylar ile kesilmektedir. $\mathrm{Bu}$ faylar hem Amanos Dağlarının genel uzantısını şekillendirmekte hem de doğu ve batı yamaçlarda yüksek eğim değerleri oluşturmaktadır. Akarsular da çoğunlukla bu tektonik hatlara entegre olmaktadır (Kuzucuğlu vd., 2019). Çalışma sahasının yer aldığı Amanosların bu kesimi de Kuzey-Güney yönlü faylarla kesilmektedir (Mülazımoğlu, 1979). Böylece kısa mesafeler içerisinde önemli yükselti farkları ortaya çıkar. Yine bu faylara bağlı olarak Amanosların hem doğu kesiminde hem de bu yörede çok sayıda sıcak ve mineralli su kaynakları çıkışları olmaktadır (Mülazımoğlu, 1979). Çalışma sahasında yerleşmeyi teşvik eden sıcak su kaynağı da faylanmalar sonucu oluşmuştur. 2019 yılının Kasım ayında, 20,5 ${ }^{\circ} \mathrm{C}$ ortam sıcaklığında vadi kenarından çıkan suyun sıcaklığ $22,8^{\circ} \mathrm{C}$, debisi ise 1 lt/sn olarak ölçülmüştür.

\subsection{JEOMORFOLOJIKFAKTÖRLER VEMORFOMETRIK ANALIZLLR}

Amanos Dağlarının batı kesimi, jeomorfolojik olarak kabaca, biri yüksek dağlık, diğeri ise onun önünde denize kadar uzanan dağ eteği ovası olarak tanımlanabilir. Bu iki alan birbirinden K-G yönlü faylarla ayrılmıştır. Dağlık alan hemen tamamen
Mesozoyik yaşlı kalkerler ve ofiyolitlerden oluşmuş̧ur. Dağ eteği ovası ise genellikle iri çakıl ve bloklardan oluşmuştur (Mülazımoğlu, 1979). Çalışma sahası ise daha çok dağlık alan üzerinde yer almaktadır. Havzanın jeomorfolojik özelliklerinin tespiti amaciyla; yükselti-eğim analizleri, hipsometrik eğri ve hipsometrik integral analizi şeklinde morfometrik analizler gerçekleştirilmiştir.

\subsubsection{Yükselti ve Eğim Analizleri}

Gökgöldere ve bu derenin kollarından oluşan mevsimlik akarsuların oluşturduğu havza yaklaşı $29 \mathrm{~km}^{2}$ alan kaplamaktadır. Saha, morfolojik olarak oldukça engebeli ve yüksektir. Akarsular tarafından derince yarılmış ve parçalı bir görünüme sahiptir. Zira kısa mesafe içerisinde 350 m yükseltiden 1960 m'lere çıkılmaktadır. Havzanın doğusu yükseltinin en fazla olduğu kesimdir (Şekil 3a). Ortalama eğim değerleri 18 - 20 dereceler arasındadır (Şekil 3b). Gökgöldere vadisi, Gökgöl yaylası ile Ilıcalar arasında oldukça daralmaktadır. Vadinin hamama açıldığı noktada yamaç eğimi $90^{\circ}$ 'yi bulmakta hatta yer yer ters eğim görülmektedir (Şekil 3b). Bu kesimde vadi genişliği ise 2 m'nin altına düşmektedir. $\mathrm{Bu}$ durum Ilıcalar yerleşmesinin kuzeydoğusundaki dar boğazı adeta bir sifon özelliğine dönüştürmektedir. Havzada yüksek eğim değerlerine bağlı olarak dağlık alandan hızla inen sular, eğimin azaldığı ve akarsu kanalının daraldığı yerde aniden yavaşlamakta dolayısıyla göllenmekte ve taşkınlara sebep olmaktadır. Akarsu kanal veya oluklarının boyutları ve bunların zemin yapıları da su kütlesinin hareket hızını belirlemede etkili olmaktadır. Bazı durumlarda bu özellikler, sel ve taşkın oluşumunu hazırlayan faktörler de olabilmektedir.

\subsection{Hipsometrik Eğri ve Hipsometrik İntegral Analizi}

Morfometrik analizler kapsamında çalışma sahasının Hipsometrik Eğrisi oluşturulmuştur. Bu eğri, bir havzanın yükselti değerlerinin alansal dağılışına oranlanması ile hesaplanır, böylece bölgenin genel yükseklik özellikleri hakkında bilgi verir. Toplam alan ile toplam yükseklik verileri kullanıldığından dolayı yerel alan ve yerel yükseltiden farklı bir şekilde genelleştirilmiş değer oluşturulur. Hipsometrik eğrinin şekli gelişim evrelerine bağlı olarak her bölgede belirgin farkl11ıklar göstermektedir. Bu indiste yerel alan yükseltisi (a) bütün havza alan yükseltisine (A) oranlanır (a/A). Gençlik döneminde hipsometrik eğri değeri büyüktür (Strahler, 1952). Belirli sahalar için Hipsometrik eğrinin şeklindeki değişiklikler ile hipsometrik integraldeki değer değişimleri erozyon ve tektonik güçlerin dengesizliği ile ilişkilidir (Strahler, 1958; 
Weissel vd, 1994). Elde edilen eğrinin dış bükey olması arazide akarsuların tektonizmanın etkisinde olduğunu ifade etmektedir. Eğri içbükey bir görüntü veriyorsa bu havzanın jeomorfolojik gelişiminde akarsuların tektonizmadan daha etkili olduğu izlenimini vermektedir. Buna göre çalışma sahası aşınımında tektonik hareketlerin etkili olduğu ve sahanın aşınımın gençlik evresinde olduğu anlaşılmaktadır (Şekil 4). Sahanın Hipsometrik İntegral değeri ise sahanın erozyona karşı duyarlılığı ile ilgili fikir vermektedir. İntegral değerinin yüksek olması erozyon değerlerinin de yüksek olabileceği anlamındadır. Değerler 0 ile 1 arasında değişmektedir. Değeri 0'dan uzaklaşması sahanın erozyon potansiyelinin yüksek olduğunu gösterir (Antonio Pedrera, et al. 2009; ). Hipsometrik integral;

$$
H i=\frac{H_{\text {ort }}-H_{\min }}{B h}
$$

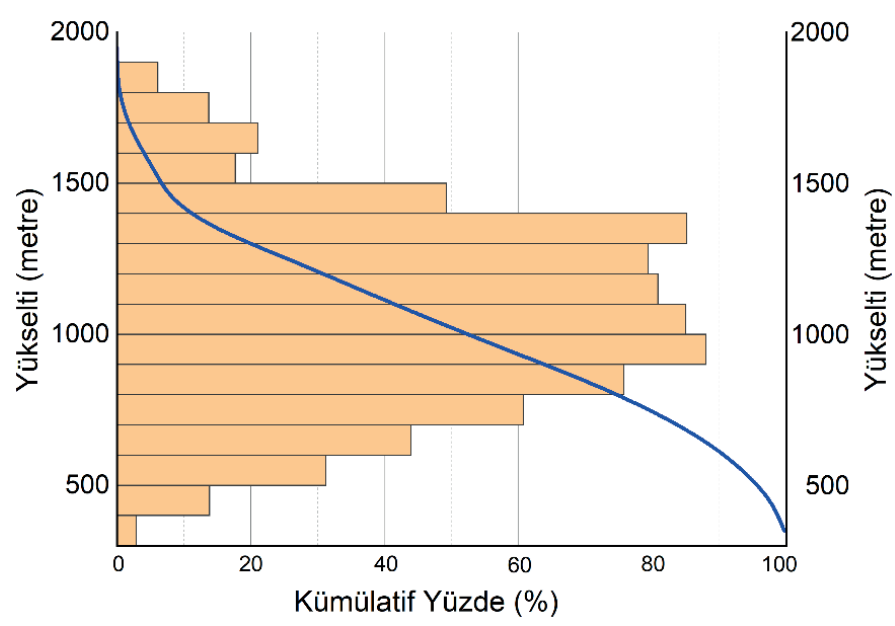

Şekil 4: Çalışma Sahası Hipsometrik Eğrisi. Figure 4: Hypsometric Curve of The Study Area.

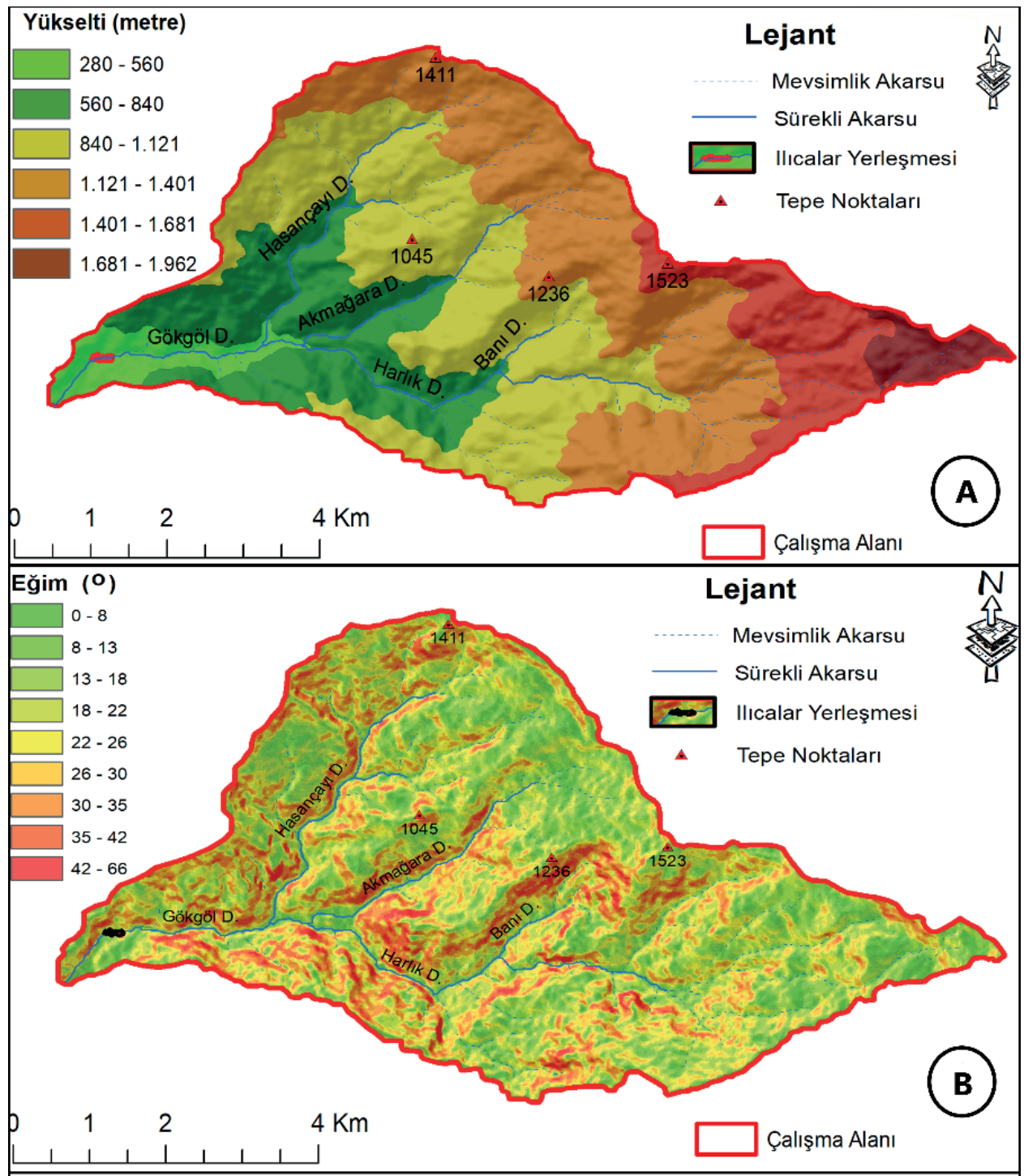

Şekil 3: (A) Çalışma Alanının Yükselti Basamakları Haritası; (B) Eğim Haritası.

Figure 3: (A) Topographic Elevation Map of The Study Area; (B) Slope Map. 
Fotmülü ile bulunur. Hort: Ortalama yükseklik, Hmin: En düşük yükselti değeri, $B h$ (En yüksek nokta değeri ile en düşük nokta yükseklik değeri arasındaki fark) (Strahler, 1952) Buna formüle göre havzanın hipsometrik integral değeri 0,44 olarak hesaplanmıştır. Bu değere göre havza aşınım evresinin gençlik safhasındadır ve erozyon değeri yüksektir.

\subsection{KLIMMATOLOJIKK FAKTÖRLER}

\subsubsection{Genel İklim Özellikleri}

Erzin (Yeşilkent) Meteoroloji İstasyonunun uzun yıllar (19872002) verilerine göre, Erzin ve yakın çevresinin yıllık sıcaklık ortalamas $18,9^{\circ} \mathrm{C}$ 'dir. Yıllık toplam yağış ortalamas $922 \mathrm{~mm}$ ve aylık maksimum yağış ortalaması ocak ayında 123,7 mm'dir. Eylül ayında maksimum yağış ortalaması ise 54 mm'dir (Tablo 1). Sahada, Köppen iklim sınıflandırmasına göre Csa grubu olan sıcak yaz aylarının hüküm sürdüğü Akdeniz iklimi özellikleri hakimdir. Saha, Thorndwait iklim sinıflandırmasına göre ise " $C 2$ B'4 s2 b'4 Yarı Nemli 4. Derece Mezotermal Su noksanı yaz mevsiminde ve çok kuvvetli olan tali iklim" özellikleri sunmaktadır.

\subsubsection{Rüzgâr Özellikleri}

Sahada hâkim rüzgâr yönü güneydoğudur (SE). Hâkim rüzgâr yönü olarak ikinci sırada ise güneybatı (SW) gelmektedir. Güney sektörlü rüzgârlar toplam rüzgârların \% $\% 6,3$ 'ünü oluşturur (Grafik 1). Rüzgârların ortalama hızları $2,48 \mathrm{~m} / \mathrm{sn}$. ( $8,92 \mathrm{~km} / \mathrm{saat})$ dir. $\mathrm{Bu}$ durum rüzgâr hız değerlerinin Bofor ölçeğinde 2'ye karşılık geldiğinin yani hızın yüksek olmadığının göstergesidir. Ancak hâkim rüzgâr yönünü güney sektörlü rüzgârların oluşturması, havzanın yağış almasında etkilidir. Özellikle güneybatı sektörlü rüzgârlar maritim hava kütlelerinin havzaya taşınması ve orografik yükselme yağış oluşumunda etkili olmaktadır.

Çalışma sahası için NOAA (Amerikan Ulusal Okyanus ve Atmosfer Dairesi)'nın 24-25/Eylü1/2014 Global Veri Asimilasyon Sistemi (GDAS) arşiv verilerinden yararlanılarak HYSPLIT (The Hybrid Single Particle Langrangian Integrated Trajectory Model) modeli üretilmiştir (Stein vd. 2020). Bu modele göre hava akımı 24.09.2014 tarihinden 25.09.2014 tarihine kadar

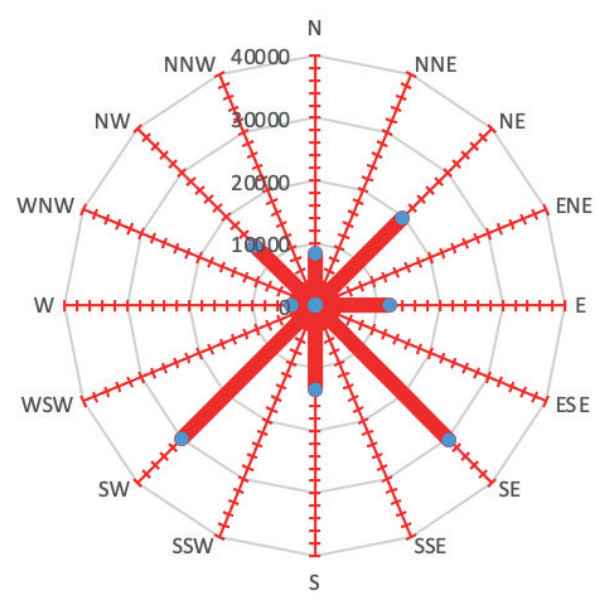

Grafik 1: Erzin Meteroroloji İstasyonu'na göre hâkim rüzgâr yönleri (1987-2002).

Graph 1: Prevailing wind directions according to Erzin Meteorology Station (1987-2002).

batıdan doğuya doğru Gökgöldere havzasında odaklanacak şekilde olmaktadır. Bu veri Greenwich saatine göre olduğundan yağışın meydana geldiği periyod 24.09.2014 günü saat 21:00 civarında yoğunlaşmaya başlamaktadır (Şekil 5A). Gökgöldere ve yakın çevresine yağış bırakan hava, daha sonra kuzeydoğuya yönelip Amanosları aştıktan ve Islahiye havzalarına yağış bıraktıktan sonra doğuya doğru dağılmaktadır (Şekil 5B).

\subsubsection{Yağış Özellikleri}

2014 yılının Eylül ayında uzun yıllar ortalamasının çok üzerinde toplam 228,6 $\mathrm{mm}$ yağış gerçekleşmiştir. $\mathrm{Bu}$ aylık yağışın \%31,5’i (69.6 mm) sel felaketinin yaşandığı 24-25 Eylül 2014 tarihinde gerçekleşmiştir. Bütün bu yağışın saat başına düşen miktarı yaklaşık $10 \mathrm{~mm}$ 'dir ve bu da belirtilen günde şiddetli bir yağı̧s olduğunun göstergesidir. Zira Meteoroloji Genel Müdürlüğü verilerine göre, 480 dakikada yağış şiddet eşiği 44,7 mm iken Erzin'e 420 dakika içerisinde 69,6 mm yağış düşmesi yağışın çok şiddetli olduğu konusunda fikir vermektedir. Yine aynı ay içerisinde toplam yağışı \%40'ı (92,7 mm) 28 Eylül 2014'te gerçekleşmesine rağmen yağış 27 ve 28 Eylül tarihlerinde 38 saate dağılmıştır. Buna göre ortalama olarak saat başına düşen yağış miktarı 2,4 mm gibi bir değerdir ve bu 24 Eylül tarihinde gerçekleşen yağış şiddetinin 1/4’ü kadardır.

Tablo 1: Sıcaklık ve Yağış Ortalama Değerleri.

Table 1: The Mean Value of Temperature and Precipitation.

\begin{tabular}{|c|c|c|c|c|c|c|c|c|c|c|c|c|c|}
\hline Aylar & 0 & Ş & $M$ & $N$ & $M$ & $H$ & $T$ & $\boldsymbol{A}$ & $E$ & $E$ & $K$ & $\boldsymbol{A}$ & Yıllık \\
\hline Ortalama Sıcaklık $\left({ }^{\circ} \mathrm{C}\right)$ & 9,3 & 10,1 & 13 & 17,6 & 21,7 & 25,3 & 27,9 & 28,3 & 26 & 21,5 & 15,1 & 10,6 & 18,9 \\
\hline Yağış Ortalaması (mm) & 93,3 & 109 & 116 & 88,3 & 73,1 & 41 & 42,1 & 14,7 & 33,2 & 74 & 115 & 122 & 922 \\
\hline Maksimum Yağış(mm) & 123,7 & 71,6 & 56,4 & 58,1 & 85,4 & 41 & 81,9 & 24,8 & 64 & 80,6 & 113,3 & 90,1 & 123,7 \\
\hline $50 \mathrm{~mm}$. ve üzerinde yağış olan Gün Sayısı Ortalaması & 0,38 & 0,25 & 0,06 & 0,06 & 0,25 & & 0,06 & & 0,13 & 0,31 & 0,38 & 0,31 & 2,19 \\
\hline
\end{tabular}


Sel felaketinin yaşandığ gün Erzin 69,6 mm yağış almıştır. $\mathrm{Bu}$ yağış değeri, Schreiber formülü kullanılarak yapılan enterpolasyonda havza içerisinde çok daha yüksek değerler göstermektedir (Şekil 6). Havza yağış değerleri $80 \mathrm{~mm}$ ile 153,6 $\mathrm{mm}$ arasında değişmekte, ortalama ise $117 \mathrm{~mm}$ olmaktadır. Yağıştaki bu artış ise yüzeysel akışla birlikte vadi içinde Ilıcalar'a ulaşmadan önce hızla bir su birikmesine yol açan bir faktör olmuştur. Şiddetli yağışın meydana geldiği 24-25 Eylül 2014 tarihinden önce Eylül ayı içerisinde yöreye $32,4 \mathrm{~mm}$ yağış düşmüştür ve bu yağış afetten üç gün öncesine kadar iki-üç gün aralıklarla devam etmiştir. Bu durum şiddetli yağıştan (MGM, 2020) önce toprakta belirli miktarda nem bulunması bakımından önemli bir husustur.

Sel felaketinin yaşandığı tarihte Erzin’e $69.6 \mathrm{~mm}$, güneyde yer alan Dörtyol'a sadece $3.4 \mathrm{~mm}$, Amanos dağlarının doğu yamacında Hassa'ya $54.4 \mathrm{~mm}$ ve İslâhiye'ye $98.6 \mathrm{~mm}$ yağış düşmüştür. Ilıcalar ile aynı veya çok yakın zaman dilimi içerisinde İslâhiye'de (Gaziantep) de sel olayı yaşanmıştır. Sağanak yağış ile birlikte 5 mahallede hasarlar oluşmuş, bir ev

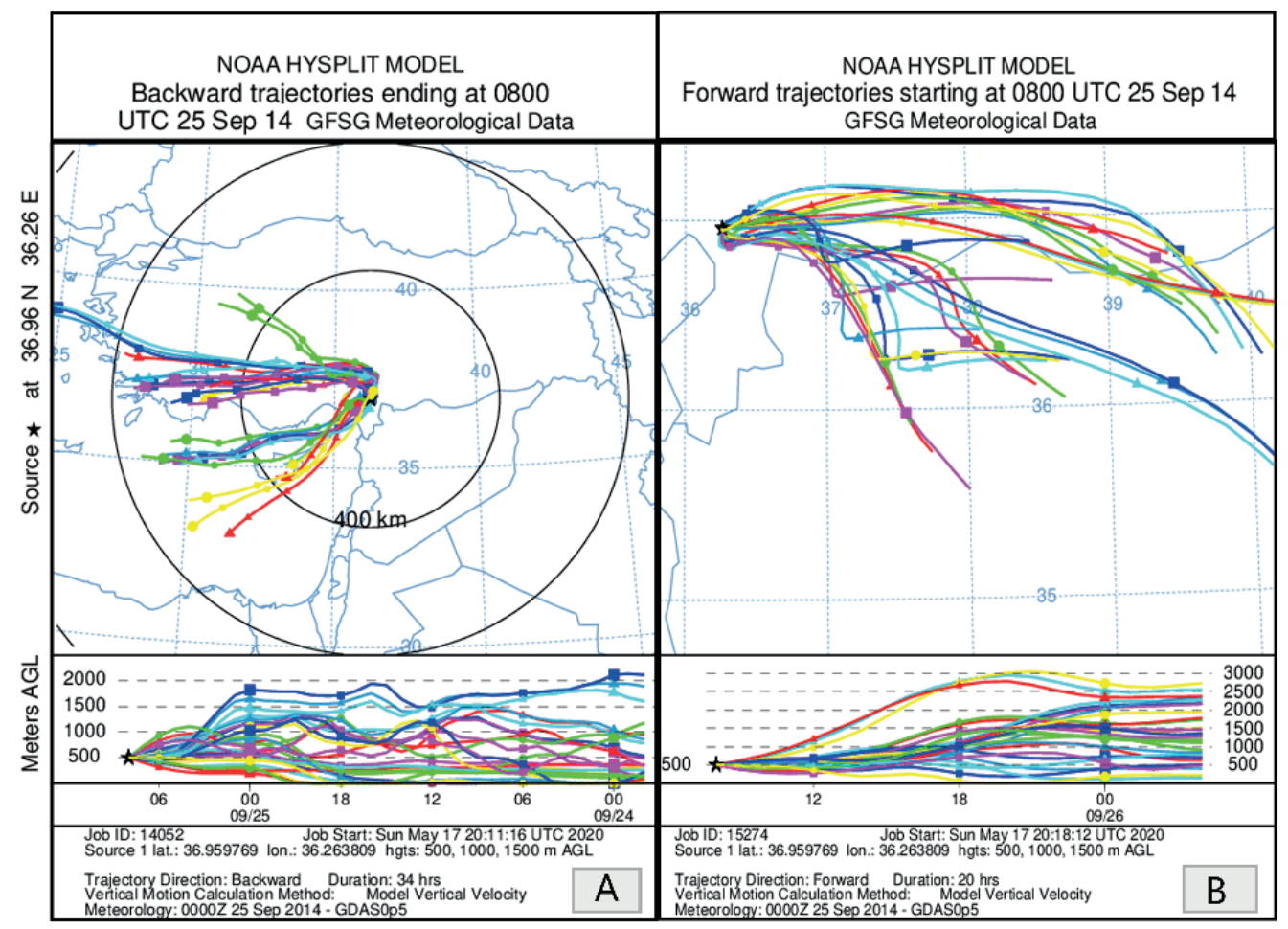

Şekil 5: Çalışma Alanında NOAA Hysplit Modeline Göre Hava Akımları A. 24-25.09.2014 tarihleri arası, B. 25-26.09.2014 tarihleri arası.

Figure 5: Air Flows According to NOAA Hysplit Model in The Study Area, A. Between 24.09.2014 and 25.09.2014, B. Between 25.09.2014 and 26.09.2014.

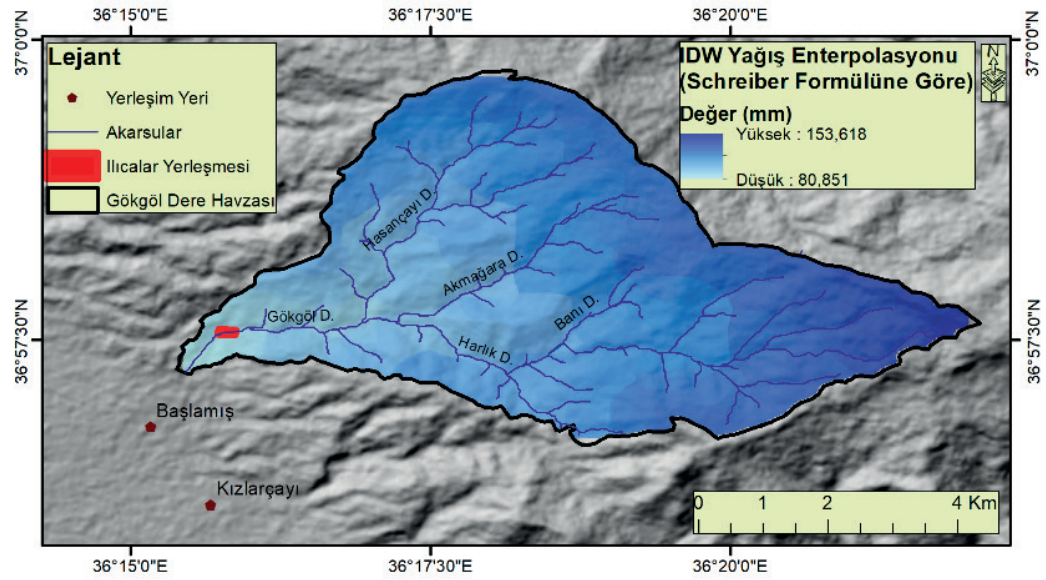

Şekil 6: Çalışma Alanında Sel Felaketinin Yaşandığı Güne Ait IDW Yağış Enterpolasyonu.

Figure 6: IDW Rainfall Interpolation of the Study Area On The Flood Day. 
ve iki köprü yıkılırken 52 küçükbaş hayvan telef olmuştur. Şiddetli yağış aynı zamanda yollarda çökmeye neden olurmuştur (Beyaz Gazete, 2014).

\subsection{HIDROGRAFİK FAKTÖRLER}

Drenaj yoğunluğu; havza içerisindeki akarsuların uzunluğunun toplam akarsu havzası alanına oranıdır ve $\mathrm{km}^{2}$ ye düşen akarsu uzunluk oranını vermektedir. Burada sürekli ve mevsimlik akarsu farkı yoktur. Hepsi hesaba dâhil edilerek $\mathrm{Dd}=\mathbf{\Sigma} \mathrm{L} / \mathrm{A}$ formülü kullanılır (Bu formülde Dd: Drenaj yoğunluğu, L: toplam akarsu uzunluğu $(\mathrm{km}), \mathrm{A}$ : alan $\left(\mathrm{km}^{2}\right)$. Drenaj yoğunluğu mil² cinsinden 1 'den düşük değerlerde başlamakta ve 20'ye kadar çıkabilmektedir (Gregory ve Walling, 1968). Drenaj yoğunluğu değerinin yüksek olması, erozyon değerlerinin fazla ve bitki örtüsünün seyrek olduğu anlamına gelmektedir. Ayrıca bu kesimlerde yamaç eğimleri de fazla olur ve akarsuların boyları kısalır (Schumm, 1956; Elbaş1 ve Özdemir, 2018). Düşük drenaj yoğunluğu değeri ise sahada infiltrasyonun yüksek olduğunu, örneğin kireçtaşı gibi geçirgenliği yüksek kayaçların bulunduğunu veya sert ve dayanıklı kayaçların bulunduğunu gösterebilmektedir. Çalışma sahasında, akarsu drenaj yoğunluğu 4,23 gibi bir değer olarak hesaplanmıştır (Şekil 7). Bu orta-yüksek bir değerdir ve havzanın vadilerle çokça parçalandığını göstermektedir. Bu özellik diğer faktörler ile birlikte, sel felaketinin yaşandığı günde akarsu debisini $138 \mathrm{~m}^{3}$ / sn'ye kadar çıkmıştır (DSİ, 2016).

Bitki örtüsü yüzeysel akışı etkileyen fiziki faktörlerdendir. Bitki yoğunluğu ise yüzeysel akış hızını düşüren ve infiltrasyonunu arttıran bir faktördür (Turoğlu, 2011). Buna karşılık bitki örtüsü tahribi yüzeysel akış hızının artmasına yol açmaktadır. Normal koşullarda doğal zeminde yüzeysel akış \%10, zemine sızma (infiltrasyon) $\% 50$ ve evapotransprasyon $\% 40$ olmaktadır. Yeşil alanı tahrip edilmiş kentlerde ise yüzeysel akış \%55, infiltrasyon $\% 15$ ve evapotransprasyon \%30 olarak tespit edilmiştir. Ayrıca bitkiler yok edildiği için evapotransprasyonun azalması yüzeysel akışı arttırmaktadır (Gülbahar, 2013). Çalışma sahasında bitki yoğunluğu söz konusudur ancak zaman içerisinde gerçekleşen bitki örtüsü tahribi yağışla düşen suyun infiltrasyonunu azaltmaktadır.

\subsection{ANTROPOJENIK FAKTÖRLER}

İnsanların arazi örtüsü üzerinde yapmış olduğu değişiklikler, sel ve taşkın gibi doğal afetlerin meydana gelmesinde bir risk unsuru oluşturmaktadır. $\mathrm{Bu}$ değişiklikler içerisinde kesme, buldozer kullanma, yakma, otlatma vb. gibi faaliyetler, taşkının peak (maksimum) değerlerini, suyun sızma ve buharlaşma hızını, materyallerin taşınma oranını, su kalitesini, suyun yüzey akışını ve yeraltı suyu deşarjını etkileyerek bir havza hidrolojisi üzerinde zararlı etkilere neden olabilmektedir (Noori vd., 2016; Ertek, 2016). Orman örtüsünün kaçak kesimlerle tıraşlanması neticesinde ortaya çıkan çıplak araziler üzerinde akış gösteren sular, zamanla arazi yüzeyinde uzunlamasına ve nispeten derin çukurlukların oluşmasına neden olur. Diğer yandan, ormanın tahrip edilmesi sonrasında yolların yapılması veya mevcut yolların genişletilmesi çalışmalarında arazilerin asfalt, beton ve parke gibi unsurlarla kaplanması geçirimliliği azaltmaktadır. Bu durum yağışlar esnasında yüzeysel akışın dikkate değer boyutlara ulaşmasına neden olmaktadır. Ormansızlaştırma ile birlikte doğal olarak gelişen kanalların yanı sıra, insanların mevcut

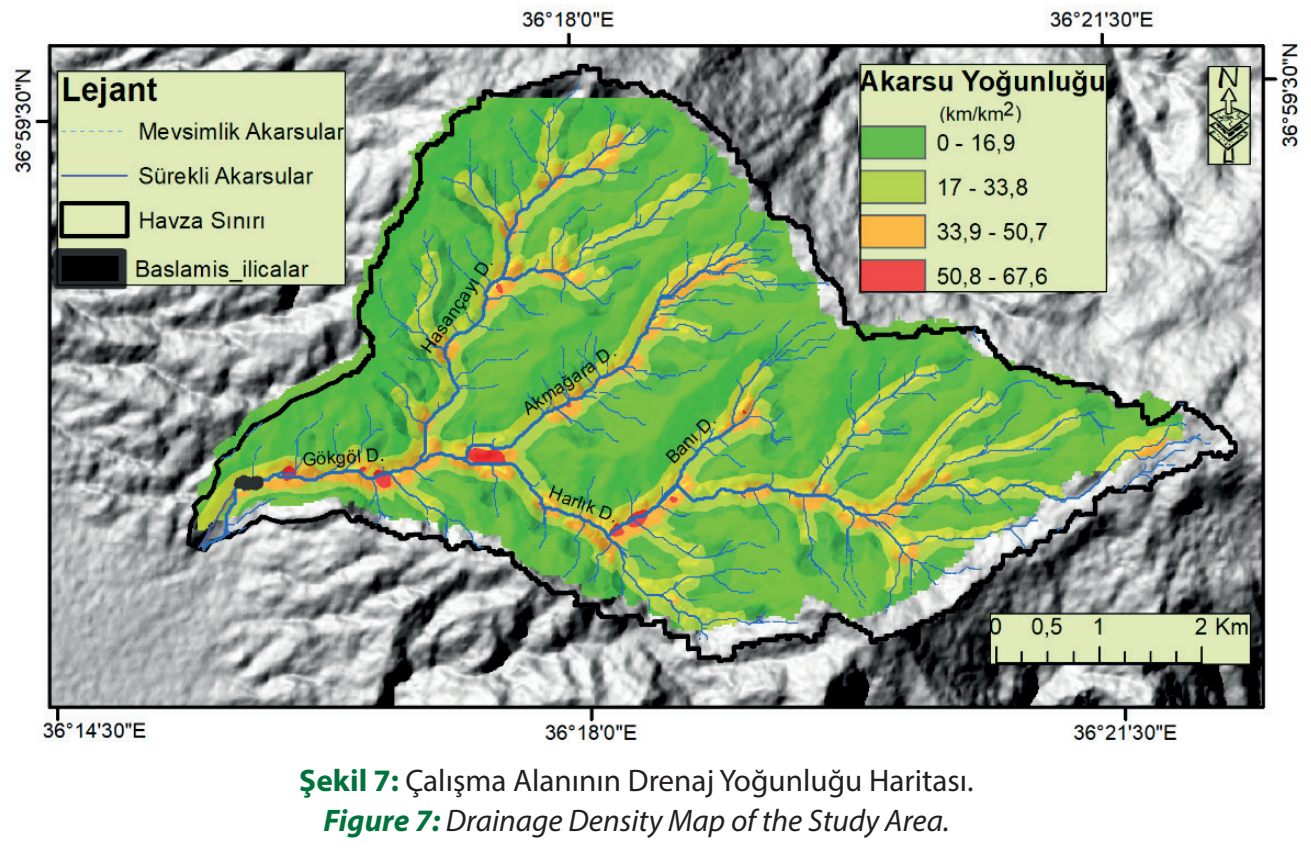


akarsu kanallarını daraltması veya herhangi bir yanlış müdahalede bulunması da aşırı yağışların sel ve taşkına dönüşmesine yol açmaktadır (Brandolini vd., 2019; Ertek, 2017).

Erzin'in Başlamış Mahallesine bağlı Ilıcalar mevkiinde 25.09.2014 tarihinde yaşanan sel felaketinin oluşmasında antropojenik faktörlerin etkisi fazladır. Sel sonrasında, Jeoloji Mühendisleri Odası Hatay İl Temsilciliği tarafindan Ilıcalar'da yapılan incelemelere ve tarafimızca afetzedelerle yapılan yarı yapılandırılmış görüşmelerden elde edilen bilgilere göre, Ilıcalar selindeinsanın doğal ortama müdahalesiüç şekilde sınıflandırılmıştır. Bunlar; (1) ormansızlaşıtırma, (2) plansız yapılaşma nedeniyle akarsu yatağının daraltılması ve (3) dere yatağı üzerinde yanlış bir şekilde köprü ve menfezlerin inşa edilmiş olmasıdır.

Sel öncesinde, Gökgöldere Havzası sınırları içerisinde akarsu vadilerinin yamaçlarında yoğun bir ağaç kesme faaliyeti gerçekleşmiştir. 24 Eylül 2014 gecesi meydana gelen sağanak yağışla düşen ve hızla akışa geçen suların taşıdığı molozlar, sürüklenen ağaç kütükleri ve dallar hamamın yer aldığı bölgede termal su kaynağının çıktığı dar boğazı tıkayarak bir set oluşturmuştur. Sular bu setin arkasında adeta bir baraj gibi birikmeye başlamış ve sonrasında artan basınçla birlikte büyük bir patlama meydana getirmiş ve topoğrafyada dahi değişiklikler oluşturmuştur (Fotoğraf 1.a; Foto 2. a1-a2). Patlama sonrasında aniden boşalan yağmur suları, Ilıcalarda sel felaketine neden olmuştur (Foto 1 b1, c1, d1). Böylece, havzada gerçekleştirilen ormansızlaştırma faaliyetlerinin sel felaketini tetikleyen en önemli antropojenik faktörlerden biri olduğu anlaşılmıştır.

Afetzedelerle gerçekleştirilen görüşmelerde, Ilıcalar'da 2014 yılı öncesinde çok sayıda sel felaketinin yaşandığı ancak bu felaketlerde dikkate değer bir zararın meydana gelmediği belirtilmiştir. Ilıcalarda meydana gelen sel ve taşkınlar üzerinde jeolojik, jeomorfolojik ve özellikle de klimatik-hidrografik faktörler etkili olmakla birlikte, 2014 y1lındaki sel felaketinin

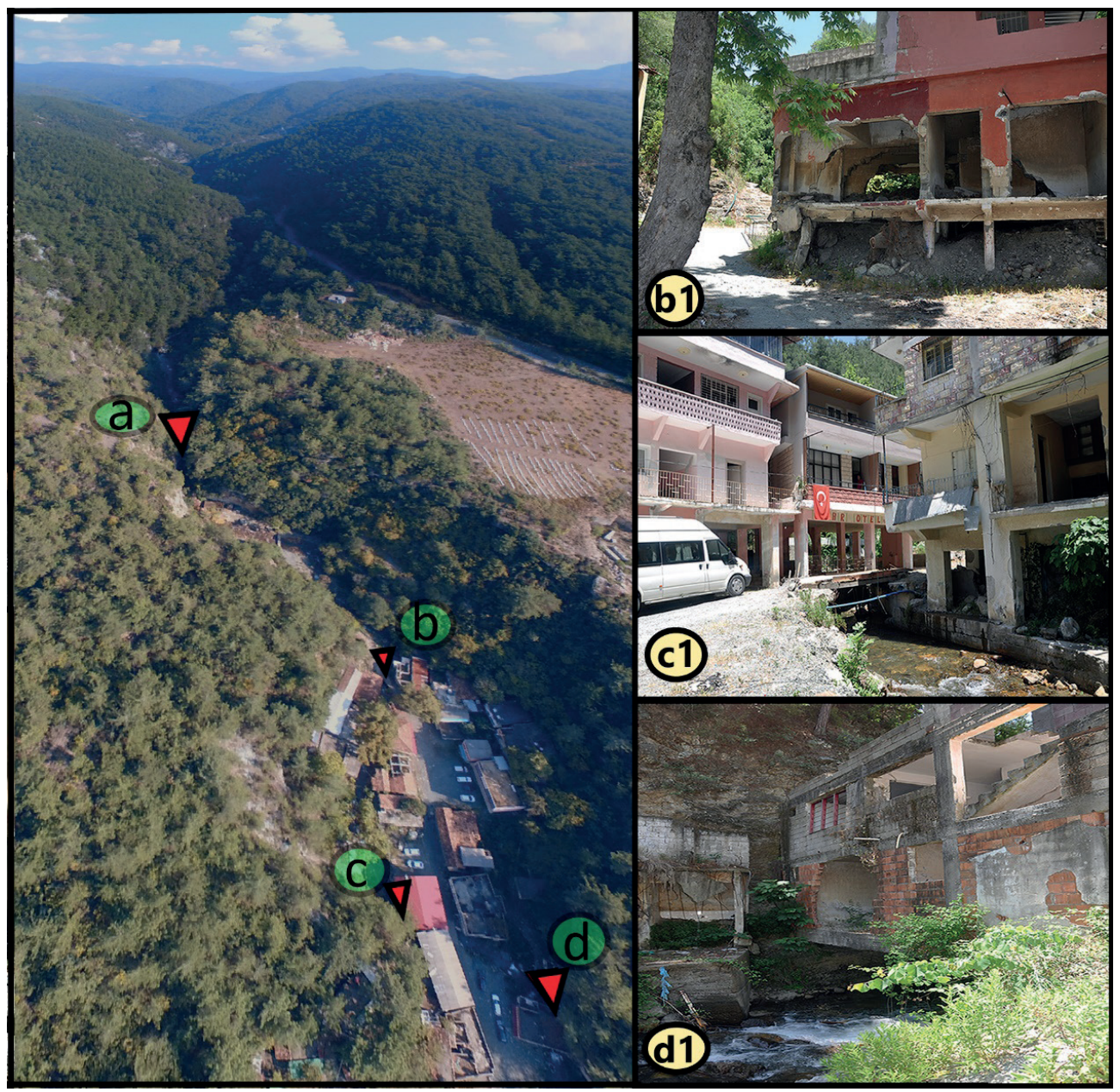

Fotoğraf 1: Gökgöldere Vadisi, a: Sıcak Su Çıkışının Yaşandığı Dar Boğaz; b1, c1, d1: Akarsu Kanalına Yapılan Müdahaleler ve Selden Zarar Gören Konutlar.

Photo 1: Gökgöldere Valley, a: Narrow Valley With Hot Spring Water; b1, c1, d1: Interventions on the River Edge and Houses Damaged by Flooding. 


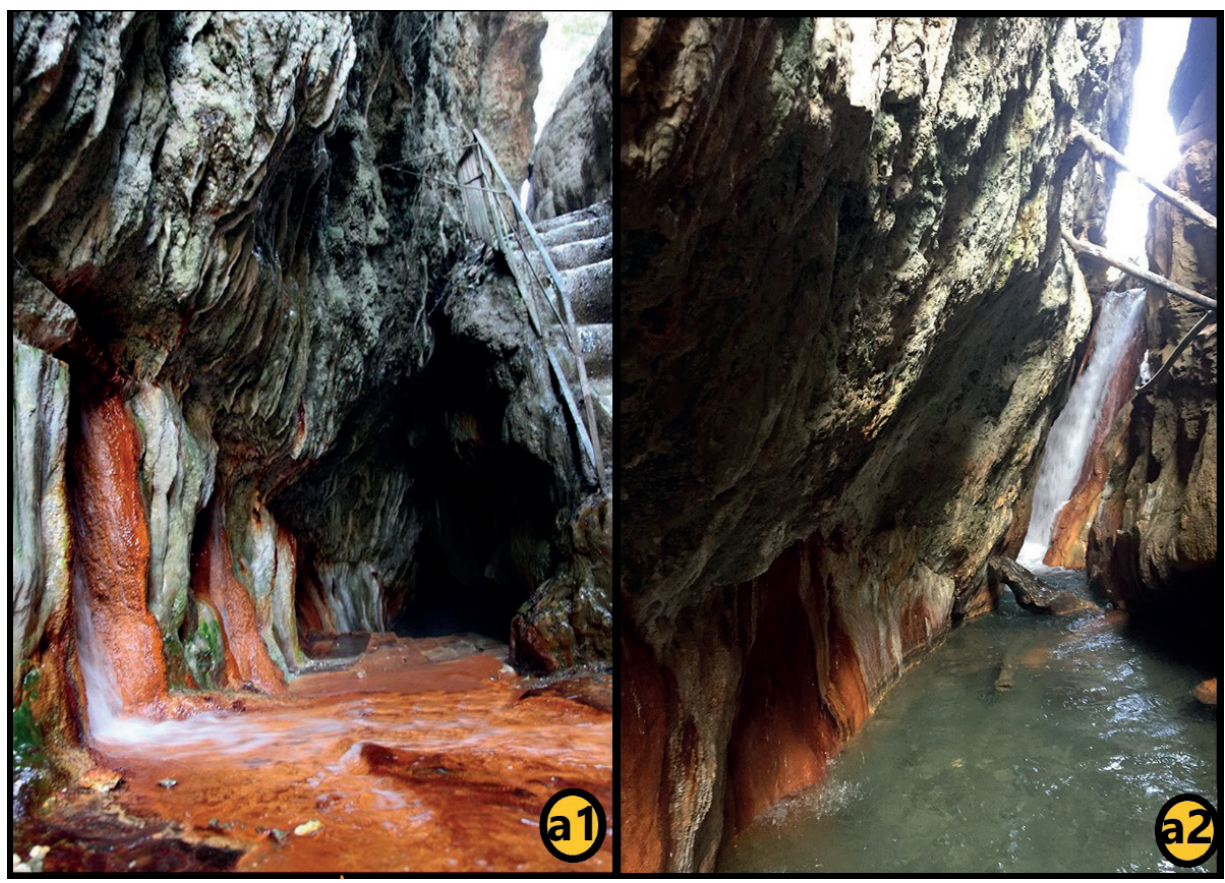

Fotoğraf 2: a1, a2: Gökgöldere Vadisi'nde Sıcak Su Çıkışının Yaşandığı Dar Boğaz ve Selin Topoğrafyada Oluşturduğu Değişiklik. Photo 2: a1, a2: The Narrow Strait Where The Hot Water Exit In Gökgöldere Valley And The Change Caused by the Flood Topography.

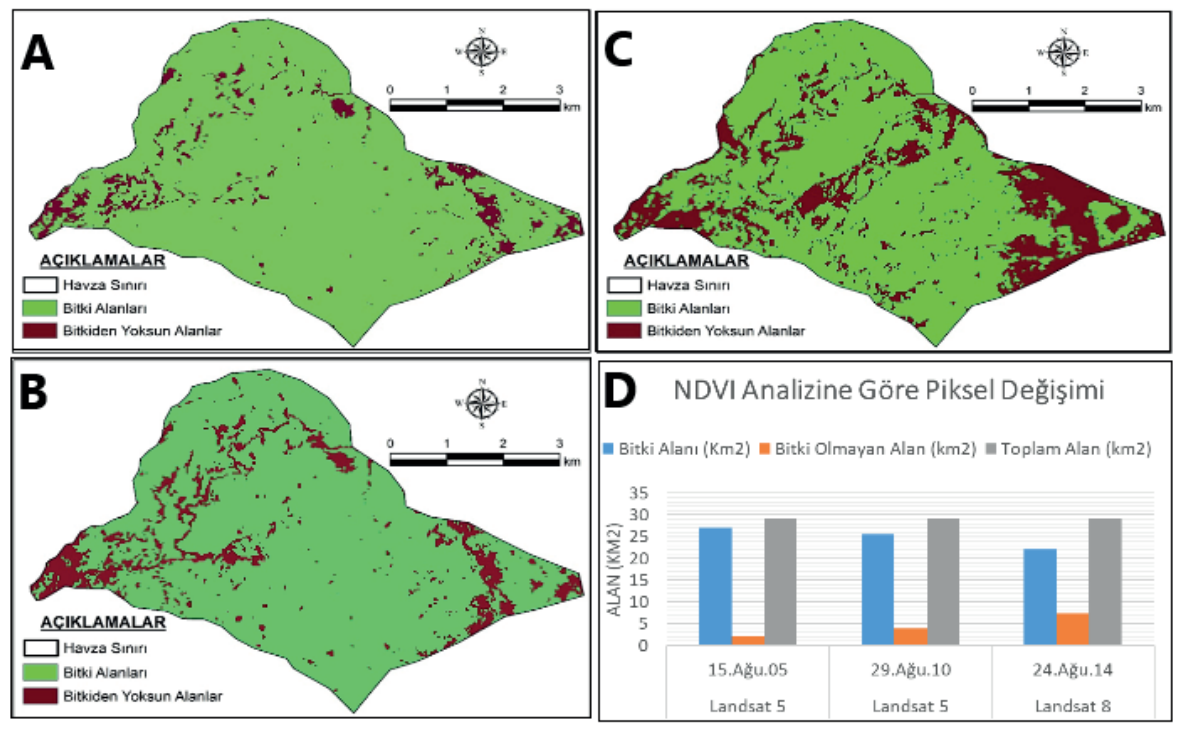

Şekil 8: Çalışma Sahasına Uygulanan NDVI Analizine Göre, Bitki Örtüsünün Alansal Değişimi (A. 2005 yılı Landsat verisi sonucu, B. 2010 Landsat verisi sonucu, C. 2014 yılı Landsat verisi sonucu, D. Yıllara göre piksel değişim oranları).

Figure 8: Spatial Change of Vegetation According to NDVI Analysis, Applied to the Study Area (A. Result of 2005 Landsat data, B. Result of 2010 Landsat data, C. Result of 2014 Landsat data, D. Pixel change rates by years).

can ve mal kayıpları ile sonuçlanması ve Ilıcaların Bakanlar Kurulu kararıyla ${ }^{3}$ afet bölgesi ilan edilmesi üzerinde de antropojenik faktörlerin önemli bir rol oynadığı anlaşılmaktadır. Bu durum havzadaki orman örtüsünde yıllar içerisinde meydana gelen değişimin (tahribat) ortaya konulmasıyla da daha iyi anlaşılmaktadır. Nitekim NDVI analizlerine göre, 2005 yılında çalışma sahasındaki bitki örtüsü $27 \mathrm{~km}^{2}$ alan kaplarken, bu değer 2010 yilında 25,5 km²'ye 2014 yilında ise $22 \mathrm{~km}^{2}$ 'ye kadar düşmüştür. 2005'ten ile 2014'de kadar geçen sürede \%25 değişim gerçekleşmiştir (Şekil 8).

3 Bakanlar Kurulu'nun 22.06.2015 Tarih ve 7883 Sayılı Karar1; 05.07.2015 Tarih ve 29407 Say1lı Resmi Gazete. 
Sel felaketinin yaşanmasındaki bir diğer antropojenik etkiyi, yerleşmenin kuruluş yeri seçiminin uygun olmaması oluşturmaktadır. Ilıcalarda inşa edilmiş olan yapılar incelendiğinde, binaların tamamının vadi tabanı içerisinde inşa edildiği ve bu durumun dere yatağının daha fazla daralmasına neden olduğu anlaşılmaktadır. Hatta yer yer kanal üzerine birkaç katlı binalar inşa edilmiştir. Yağışların az olduğu dönemlerde, sular vadinin orta kesimlerinden kanal içerisinde akış gösterirken, sağanak yağışların gerçekleştiği dönemlerde ise sular levelerden taşmaktadır. Buna bağlı olarak, yapıların da içerisinde yer aldığı vadi tabanı ve banklar sel sularına teslim olmaktadır. 2014 yılında yaşanan sel felaketinde, bu plansız yapılaşmanın olumsuz etkileri somut bir şekilde görülmüştür (Foto 3). Diğer yandan, Ilıcalar ve yakın çevresinde inşa edilmiş olan alçak köprü ve menfezler, akarsuların sürüklemiş olduğu sediman nedeniyle tıkanmış ve bu durum sel felaketini tetikleyen antropojenik faktörlerden bir diğerini oluşturmuştur.

Gökgöldere havzası içerisinde özellikle Amanos dağlarının belirli yükselti kademelerinde yayla yerleşmelerinin varlığ yerleşmelere erişimde yol yoğunluğunun arttırılması ve yol genişletme çalışmalarının yapılması sel felaketini etkileyen diğer beşerî etmenler arasında yer almaktadır (Atasoy ve Korkmaz, 2015). Yaz aylarında, sicak ve bunaltıcı hava şartlarına sahip Çukurova yerleşmelerinden yaylalara çıkanlar son yıllarda rekreasyonel faaliyetlere katılmaktadırlar. Çukurova bölgesinin en önemli yayla yerleşmelerinden biri olan Zorkun Yaylasına erişimin Gökgöldere havzası içerisinde yer alan yollar üzerinden de sağlanıyor olması ve yaz aylarında kıyı kesimi ile yaylalar arasında yoğun bir nüfus hareketliliğinin yaşanması, eğimli yamaçların doğal dengesini etkilemektedir. Havza sınırları içerisinde yer alan Kumluca, Akoluk, Gazelliyayla, Gökgölyayla, Sofular, Haçbel ve Uzunçınar gibi yayla yerleşmelerinin nüfuslarının artış göstermesi ve bu yerleşmelerin alan bakımından genişlemesi, havzanın nispeten yüksek kesimlerinde arazinin daha yoğun bir şekilde kullanıldığını göstermektedir.

\subsection{ILICALAR (ERZINN/HATAY) SELININ ETKILERI}

\subsubsection{Yerleşmeye Etkisi}

Kuruluş yeri seçimlerinde gerekli hassasiyetlerin gösterilmediği yerleşmeler, doğal afetler karşısında çaresiz kalmakta ve bu durum söz konusu yerleşmelerin yer değiştirmelerine veya terk edilmelerine neden olmaktadır. Afet

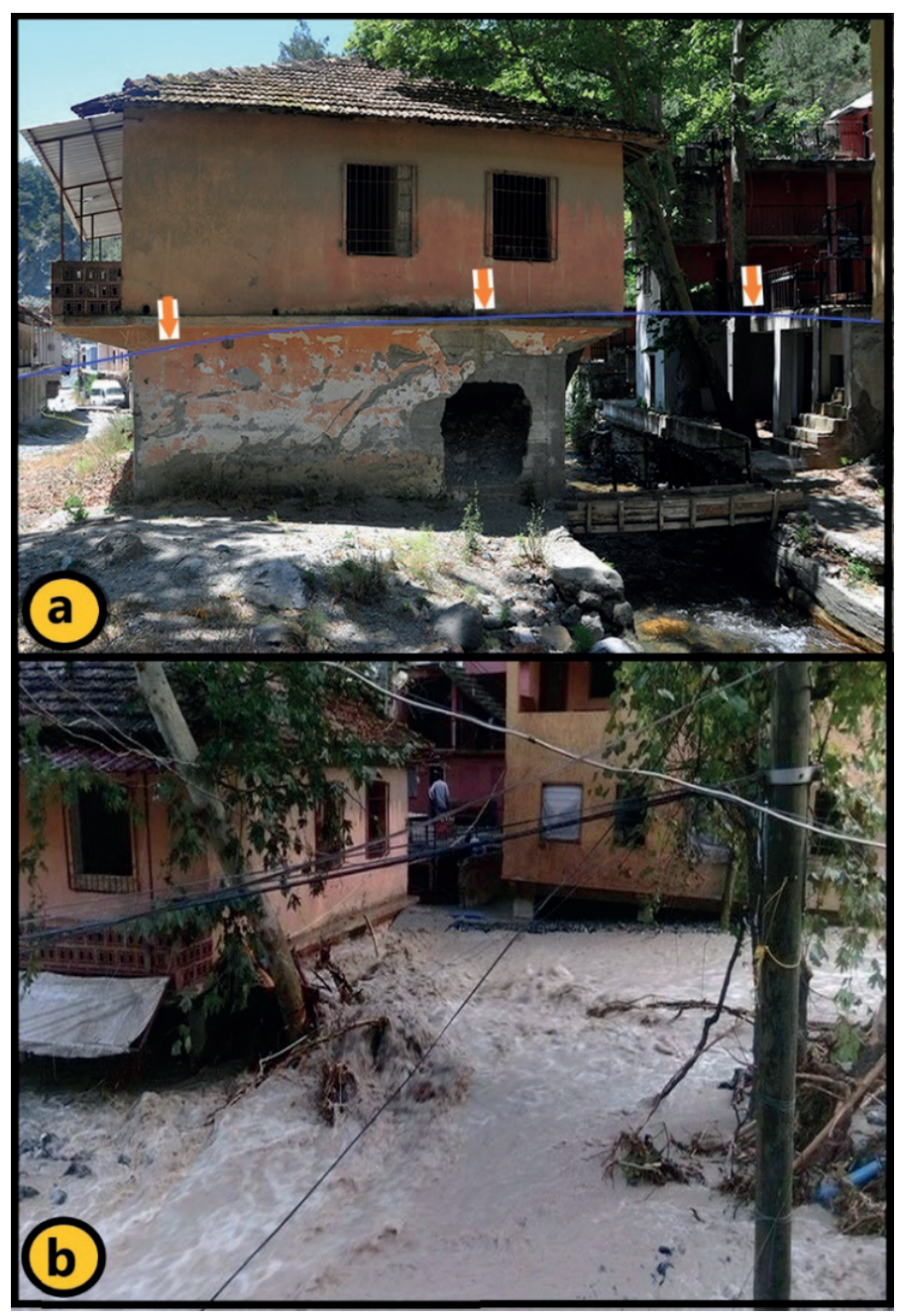

Fotoğraf 3: a. Dere yatağında inşaa edilmiş bina, selin üzerinden 6 yıl geçmesine rağmen sel felaketine ait izler üzerinde durmaktadır, $b^{4}$. Aynı bina üzerinde sel sürecindeki su seviyesi.

Photo 3: $a$. A building which built on the stream bed, the marked part is the level reached by the water in the flood $b$. The water level during the flood on the same building.

İşleri Genel Müdürlüğ̈̈’nce yaptırılan bir çalışmaya göre, ülkemizde 2008 yılındaki toplam 38.009 daimî yerleşim biriminden 5.472'si $(\% 14,4)$ heyelandan, 3.942'si $(\% 10,4)$ depremlerden, 2.924'ü $(\% 7,7)$ sel ve taşkınlardan etkilenmiştir. Afetlerden etkilendikleri için yeri değiştirilen yüzlerce yerleşmenin olduğu ortaya konulmuştur (Gökçe vd., 2008). Diğer yandan ülkemizdeki daimî yerleşmelerden farklı olarak y1lın belirli dönemlerinde yerleşilen yerleşmelerin doğal afetler sonrasında çoğunlukla terk edilmiş oldukları dikkati çekmektedir. Ilıcalar da bu yerleşmelerin somut bir örneğini oluşturmaktadır.

4 https://www.ensonhaber.com/galeri/hatay-erzin-ilcesi-sele-teslim-oldu\#8 
Gökgöldere vadisi tabanında kurulmuş olan Ilıcalarda, arazi kullanımına bağlı olarak gerçekleştirilen yanlış uygulamalar, taşkının bir afet niteliğine dönüşmesine neden olmuştur (Atasoy ve Korkmaz, 2015). Taşkın neticesinde bu akarsuyun vadisi içerisinde kaplıca turizmine yönelik olarak kurulmuş olan ve sayfiye yerleşmesi durumundaki Ilıcalar'da can ve mal kayıpları yaşanmış ve ardından yerleşme tamamen terk edilmiştir. Böylece taşkın olayı öncesinde, özellikle yaz aylarında oldukça hareketli olan ve turizmin etkisiyle rekreasyonel faaliyetlere de imkân sağlayan Ilıcalar, taşkın sonrasında kaderine terk edilmiştir. Ilıcaların, afet bölgesi olarak ilan edilmesiyle birlikte buradaki yapılar için yıkım kararı alınmıştır. Ancak, binaların yıkılmasına yönelik henüz herhangi bir girişim söz konusu olmamıştır.

\subsubsection{Turizm Faaliyetlerine Etkisi}

Doğal afetler bakımından risk taşıyan ve coğrafi şartlara dikkat etmeden kurulup gelişen yörelerde, doğal afetlerin turizm sektörünü sekteye uğrattığı ve turistler üzerinde tedirginlik yarattı̆g bilinen bir gerçektir (Emekli, 2001). Nitekim sel ve taşkınlar başta olmak üzere doğal afetler, turizm sektörünün coğrafi ortamını, manzarasını, faaliyetlerini ve cazibe merkezlerini etkiler (Berrittella vd., 2006). Önceleri turizm sektörü bakımından çekici unsurları barındıran destinasyonlar, yaşanılan doğal afetlerle birlikte "moda olma" özelliğini yitirmekte ve bu özellik çoğu zaman geri kazanılamamaktadır (Emekli, 2001).

Erzin'in Başlamış Mahallesine bağlı Ilıcalar yerleşmesinin litolojik birimler açısından çeşitlilik arz etmesi, suların mineral yoğunluğunu arttırmaktadır (Atasoy ve Korkmaz, 2015). İçme ve Ilıca sularının litresinde 5 gr'ın üzerinde mineralizasyon bulunduğu için bu sular termal, hipotonik ve karbondioksitli sular grubunda yer alır. Kaynakların su kimyas1, piper diyagramına göre değerlendirildiğinde, magnezyumlu, bikarbonatlı ve sülfatlı sular grubunda yer alır (Yalçın vd, 2004). Ilıca ve İçmeler; böbrek, idrar yolları, mide ve bağırsak, astım ve bronşit, cilt, damar sertliği ve romatizma gibi birçok rahatsızlığa iyi geldiği için halk arasında sağlık turizmi bakımından yoğun ilgi görmüştür (Kelkit, 1992; Şahin, 2007). Diğer yandan Ilıcalar mevkiinin bitki örtüsü ve su kaynakları yönünden sunmuş olduğu doğal güzellikler nedeniyle bu saha, "II. Derece Doğal Sit Alanı" olarak kabul edilmiş ve Taşınmaz Kültür Varlıklarını Koruma Kurulu'nun 23.10.1992 tarih ve 1333 sayılı kararıla koruma altına alınmıştır ${ }^{5}$. Ilıcaların bu dikkate değer özellikleri, yörenin zengin bir sayfiye yerleşmesi olarak 1960'lı yıllarda kurulup gelişmesini sağlamıştır.

Ilıcalar'ın turizm sektörüne bağlı olarak gösterdiği kuruluş ve gelişim süreçleri, yıllarını Ilıcalarda geçirmiş olan ve 2014 yılındaki sel felaketine maruz kalan afetzedelerle gerçekleştirilen görüşmelerden hareketle ortaya konulmuştur. Başlamış Mahallesi sakinleri, 1940'lı yıllarda bugünkü Ilıcalar'a içme suyu temin etmek için gittiklerini ve sonraki süreçte suyun bir şifa kaynağı olduğunun anlaşılması üzerine yörenin çekiciliğinin arttığını belirtmişlerdir. Ayrıca, önceleri derme çatma şekilde inşa edilen yapılarına yenilerinin eklenmesiyle yörenin bir sayfiye yerleşmesi haline geldiğini, termal su kaynağından yararlanmak amacıyla Adana, Gaziantep, Şanlıurfa, Kahramanmaraş ve Adıyaman gibi illerden çok sayıda insanın Ilıcalar'a geldiklerini ifade etmişlerdir.

İfade edildiği üzere, sağlık turizmi bakımından sahip olduğu önemin anlaşılmasıyla birlikte, Ilıcalar, çevre illerden günübirlikçilerin uğrak mekânı haline gelmiştir. Mayıs ayı sonlarından başlayarak Eylül ayının sonlarına kadar süren turizm sezonu içerisinde yörenin ziyaretçi akınına uğradığı, su kaynağının çıktığı noktada bir hamamın hizmet verdiği ve bu hamamın sıcak su kaynağını kullanmak isteyen hastalara saatlik olarak kiralandığı ifade edilmektedir. Ilıcaların sağlık turizmi bakımından önemli destinasyonlardan biri olarak gelişmesi neticesinde ziyaretçi sayılarının her geçen yıl artmaya başlaması, bu mevkide otel, pansiyon, apart otel ve ikinci konutların inşa edilmesini teşvik etmiştir.

Ilıcalar'da inşa edilmiş olan yapılar, 2014 yılında meydana gelen sel nedeniyle büyük zarara uğramış ve yöre sakinleri binalarını terk etmişlerdir. Bunlar içerisinde maddi durumları nispeten iyi olanlardan bazıları Aşağı İçmeler olarak tabir edilen sahada, kendi imkânlarıyla otel/pansiyon inşa ederek bu tesisleri işletmeye devam etmişlerdir. Bazıları ise, Ilıcalar'ın yeniden yerleşime açılmasınıbeklemektedir. Yöre halkı ile gerçekleştirilen görüşmelerde, afetzedeler yeniden Ilıcalara dönmek istediklerini, hayatlarının önemli bir bölümünü bu sayfiye yerleşmesinde geçirdiklerini ve yerleşmenin onlar için önemli bir gelir kaynăg 1 olduğunu belirtmişlerdir. Fakat, görüşme gerçekleştirilen afetzedeler Ilıcalar'ın afet bölgesi olarak ilan edilmesi nedeniyle bu yerleşmeye geri dönme konusunda umutlarını yitirmiş durumdadir.

5 Hatay Valiliği, Hatay Kültür Envanterleri, Cilt II, s.220. 


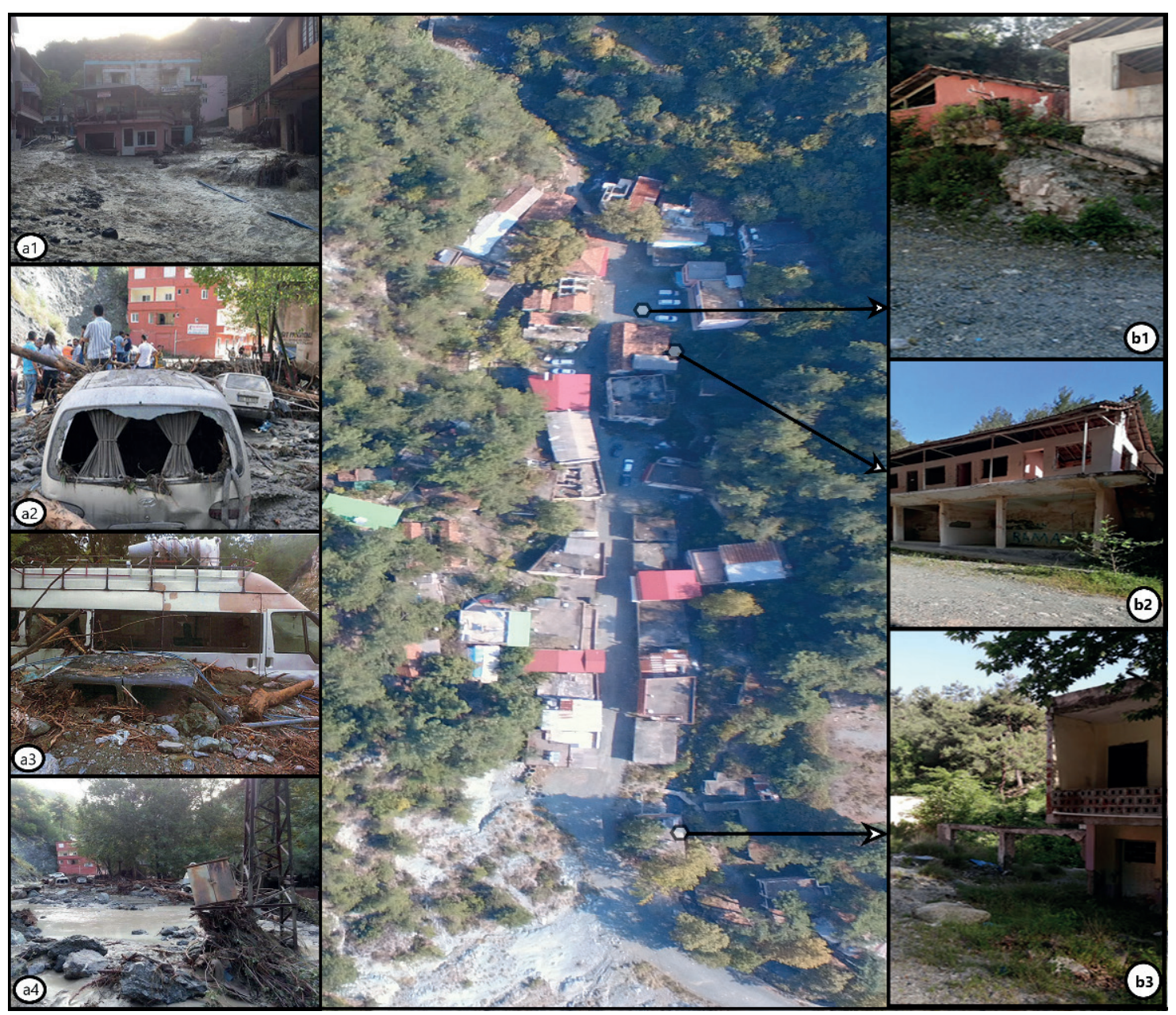

Fotoğraf 4: Ilıcalardaki Sel Felaketinin Etkileri; a1-a2-a3-a43 Maddi Kayıplar; b1-b2-b3 Can Kayıplarının Yaşandığı Konutlar. Photo 4: Effects of Flood Disaster in Ilıcalar; a1-a2-a3 Economic Losses; b1-b2-b3 Houses of Those Who Lost Their Lives.

\subsubsection{Can ve Mal Kayıplarının Yaşanması}

Hatay İl Afet ve Acil Durum Merkezi'nden elde edilen bilgilere göre, Erzin'in Başlamış Mahallesine bağlı Ilıcalar mevkiinde 25.09.2014 tarihinde yaşanan sel felaketinde 5 kişi hayatını kaybetmiş, 14 konut ve 42 işyeri önemli düzeyde zarar görmüştür. Ayrıca 1 minibüs ve çok sayıda taşıt aracı sel sularılya sürüklenerek kullanılamaz hale gelmiştir (Foto 4). Sel felaketi can kayıpları açısından değerlendirildiğinde, Ilıcalar'ın mevsimlik bir yerleşme olması ve sel afetinin turizm sezonunun neredeyse kapandığı bir dönemde gerçekleşmesi daha az can kaybının meydana gelmesinde etkili olmuştur.

Ilicalar'da meydana gelen sel felaketinde su seviyesinin yaklaşık 2-2.5 metreye kadar yükselmiş olması ve binaların alt katlarının daha çok ticari bir işletme olarak kullanılması, dikkate değer maddi kayıpların yaşanmasına neden olmuştur. Binaların alt katlarındaki bazı odaların sel ile sürüklenen materyallerle ve kumla dolması, bir internet kafedeki bilgisayarların kullanılamaz hale gelmesi, arabaların sel ile sürüklenerek ağır hasara uğramaları, otel ve pansiyonlardaki yatak, klima, nevresim vb. gibi nesnelerin zarar görmesi, söz konusu maddi kayıpların sadece bazılarını oluşturmaktadır. Önceleri tapusuz olan binaların sakinleri selden birkaç yıl önce Orman Kadastrosu 2-B Yönetmeliğ $i^{9}$ kapsamında tapularını aldıklarından, zararlarının bir kısmı devlet tarafından kendilerine ödenmiş̧tir. Sel felaketine maruz kalmış olan yöre sakinlerine, maddi kayıpların boyutları ölçüsünde devlet tarafından bir kısım nakdi yardım yapılmıştır.

\footnotetext{
6 https://www.ensonhaber.com/galeri/hatay-erzin-ilcesi-sele-teslim-oldu\#15

7 https://www.medyagazete.com/turkiye/erzinde-sel-felaketi-2-olu-h9917.html

8 https://www.jmo.org.tr/genel/bizden_detay.php?kod=7257\&tipi=17\&sube=0\#.XsRP9WgzbIU

9 "6831 sayılı Kanunun 2 nci maddesinin birinci fikrasının (B) bendine göre, orman sınırı dışına çıarılacakyerlerin tayin ve tespitinin yapılması hakkındaki yönetmelik"
} 


\section{SONUÇ}

Doğal faktörler olan, yapısal ve litolojik unsurlar, toprak yapısı, bitki örtüsü özellikleri, jeomorfolojik özellikler, meteorolojik ve klimatolojik özellikler ile drenaj sistemi gibi hidrografya özellikleri sel ve taşkınların oluşmasında etkili olan temel faktörlerdir. Ancak bu doğal etmenlerin yanı sıra sel ve taşkınların birer afet niteliğine dönüşmesinde beşerî-antropojenik faktörler de önemli etkilere sahiptir. Bu durum, insanın doğal çevresi ile olan karşıllklı etkileşimini inceleyen coğrafya biliminin sel ve taşkınlar ile ilgili çalışmalarda dikkate değer sonuçlar ortaya koyabileceğini göstermektedir. Bu çalışmada, Erzin'in Başlamış mahallesi sınırları içerisinde yer alan Ilıcalar mevkiinde 25.09.2014 tarihinde yaşanan sel felaketi coğrafi bir bakış açısıyla değerlendirilmiştir. Sel felaketine neden olan faktörlerin ortaya konulabilmesi için her şeyden önce Ilıcaların da içerisinde yer aldığı Gökgöldere havzasının coğrafi yapısı incelenmiştir. Havzada, sel ve taşkın oluşumuna neden olan her bir bileşenin etki derecesi birbirinden farklı olsa da söz konusu bileşenler bir bütün olarak değerlendirilmiş ve araştırmanın bulguları ortaya konulmuştur.

Gökgöldere havzas1, tektonik hareketler neticesinde faylanma ve yükselme ile genel jeomorfolojik görünümünü almıştır. Burada yerleşim yerinin kurulmasına sebep olan mineralli sular, faya bağlı olarak doğal yollarla ortaya çıkmış ve herhangi bir sondaja gerek kalmamıştır. Litolojik olarak, çoğunluğunu ultrabazik ofiyolit kayaçların oluşturduğu yörede bu kayaç yapısına ve kayaç çözülmesine bağlı olarak kil oluşmakta ve infiltrasyon zayıflamaktadır. Bitki örtüsünün genel olarak yoğun olmasına rağmen zemindeki kil oluşumu fazla olduğu için yüzeysel akış da fazla olmaktadır. Bunun neticesinde ise yüzeyde irili ufaklı çok sayıda dar ve derin vadi oluşmakta ve topoğrafya parçalı bir yapıya sahip olmaktadır. Vadi tabanında kurulmuş olan Ilıcaların doğusunda Amanos dağları yükseltileri kısa mesafeler dâhilinde artış göstermektedir. $\mathrm{Bu}$ da sahadaki eğim değerlerini oldukça arttırmaktadır. Gökgöldere vadisinin genişliği, Ilıcalar mevkiinde 2 metrenin altına düşmektedir. Sel felaketinden önce buranın çok daha dar, hatta mağara görünümünde olduğuna dair fotoğraflar mevcuttur. Dolayısıyla bu dar boğaz havza sularını adeta bir sifon gibi boşaltmaktadır. Bu durum dar boğazın gerisinde göllenmeye yol açarak taşkının meydana gelmesinde belirleyici bir rol oynamıştır.

Havzanın güney sektörlü rüzgârlar ile taşınan nemli hava kütleleri için orografik yağış koşulları oluşturması bir diğer özelliktir. 2014 yılının Eylül ayında uzun yıllar yağış ortalamalarının çok üzerinde yağış meydana gelmiş ve bu aylık yağışın \%31.5'i sel felaketinin yaşandığı 24-25 Eylül 2014 tarihlerinde gerçekleşmiş̧ir. $\mathrm{Bu}$ durum, belirtilen günlerdeki sağanak yağışların sel ve taşkına neden olan bir diğer faktör olduğunu göstermektedir. Diğer yandan araştırma sahasına yönelik drenaj yoğunluğu hesaplamaları, havzanın vadilerle çokça parçalandığını göstermiş, bu özellik diğer doğal bileşenlerle birlikte değerlendirildiğinde akarsu debisinin artmasına neden olarak sel ve taşkınları tetiklemiştir.

Ilıcaların da içerisinde yer aldığı Gökgöldere havzasında, beşerî faaliyetler sonucu ortaya çıan orman tahribi, hızlı ve plansız gelişen yapılaşma ile akarsu kanallarının daraltılması, yerlerinin değiştirilmesi, kanal üzerine inşa edilen köprüler ve menfezler ve hatta yine kanal üzerine inşa edilen binalar akarsu drenajını zorlaştırmıştır. $\mathrm{Bu}$ durum, sel felaketinin yaşanmasında beşerî-antropojenik faktörlerin ne kadar önemli bir etkiye sahip olduğunu ortaya koymuştur. Böylece, doğanın cömertçe sunduğu imkânları yarım asırdan fazla bir süre kullanan Ilıcalılar, mekânın bünye ve imkânlarını hesaba katmamanın ve doğayı planlı bir şekilde yönetememenin faturasını ağır bir şekilde ödemişlerdir.

Yapılaşmaların akarsu vadisi tabanında gerçekleştirilmesi gibi havzaya yapılan yanlış müdahale neticesinde kurulmuş olan Ilıcalarda yeniden yerleşime izin verilmemesi önem arz etmektedir. Bu konuda, ilk adımlar atılmış olup, saha bir afet bölgesi olarak ilan edilmiş, yapılaşma yasağı getirilmiş ve mevcut yapılara yönelik yıkım kararı verilmiştir. Sahadaki yapıların yıkılması ve yapı kalıntılarının tamamen temizlenmesi sonrasında Gökgöldere'nin 1slah edilmesi, mineralli suyun değerlendirilmesi amacıyla tesisleşmeye gidilecekse bunun vadi dışında inşa edilmesi uygun olacaktır. Vadide afet risklerini en aza indirebilmek ve doğanın dengesini koruyabilmek için ormanlık alanlarda kaçak kesimlere izin verilmemesi, havza içerisinde konut, endüstriyel tesis, maden ocakları, sosyal veya kültürel tesisler gibi yapılaşmaların önüne geçilmesi büyük önem arz etmektedir.

Ilıcalar, yerleşime elverişli bir sahada yer almamasına rağmen dikkate değer doğal güzelliklere sahiptir. Sahanın ekoturizm anlayışı doğrultusunda, günübirlik turizm aktivitelerinde değerlendirilmesi mümkündür. Trekking ve zipline, doğa fotoğrafçıllığı gibi sporlar bu aktivitelerden bazıları olabilir. Ayrıca bitki örtüsü çeşitliliği, faylar, kendiliğinden çıkan sıcak sular, jeomorfolojik özellikleri doğa eğitimi için de uygun birtakım özelliklere sahiptir. Bu aktivitelerinin teşvik edilmesi gerekmektedir. 
Teşekkür: Çalışma sahasında insansız hava aracı uçurarak, hava fotoğraflarını edinmemizi sağlayan, bölümümüz Dr. Öğr. Üyesi Mesut ŞIMŞEK’e ve arazi çalışmalarımıza destek veren, sel felaketinden etkilenen sahıslarla temasa geçmemizi sağlayan Başlamış Mahallesi muhtarı İbrahim KURT'a teșekkürü bir borç biliriz.

Hakem Değerlendirmesi: Dıș bağımsız.

Çıkar Çatışması: Yazarlar çıkar çatışması bildirmemiştir.

Finansal Destek: Yazarlar bu çalışma için finansal destek almadığını beyan etmiştir.

Peer-review: Externally peer-reviewed.

Conflict of Interest: The authors have no conflict of interest to declare.

Grant Support: The authors declared that this study has received no financial support.

\section{KAYNAKÇA/REFERENCES}

Abbott, P. L. (2008). Natural Disasters, Sixth Edition. New York: McGraw-Hill.

AFAD (2020). T.C. İçişleri Bakanlığı Afet ve Acil Durum Yönetimi Başkanlığı (2020) Doğa Kaynaklı Olay İstatistikleri.

Pedrera, A., Peña, J. V. P., Zaldívar, J. G., Azañón, J. M., Azor, A. (2009). "Testing the sensitivity of geomorphic indices in areas of low-rate active folding (eastern Betic Cordillera, Spain) Geomorphology, 105 (2009) 218-231.

Atasoy, A. \& Korkmaz, H. (2015). Erzin (HATAY)'de Yanlış Arazi Kullanımına Selin Tepkisi. IV. Ulusal Jeomorfoloji Sempozyumu Bildiriler Kitabı (s.444-456), SAMSUN.

Avcı, V. \& Sunkar, M. (2015). Giresun'da Sel ve Taşkın Oluşumuna Neden Olan Aksu Çayı ve Batlama Deresi Havzalarının Morfometrik Analizleri. Coğrafya Dergisi, 30, 91-119.

Bahadır, M. (2014). Samsun'da meydana gelen 4 Temmuz ve 6 Ağustos 2012 taşkınlarının klimatik analizi, Coğrafya Dergisi, 29, 28-50.

Başbakanlık Afet ve Acil Durum Yönetimi Başkanlığı, Türkiye Ulusal Afet Arşivi (TUAA) Sistemi. (tarih yok). 1900-2010 Dönemleri Afet Istatistikleri.

Berrittella, M. B., Bigano, A., Roson, R., Tol, R. S. J., (2006). A general equilibrium analysis of climate change impacts on tourism. Tourism Management, 27(5), 913-924.

Beyazpirinç, M. \& Usta, D. (2018). Türkiye Jeoloji Haritaları Serisi, Antakya O-36 Paftası. Ankara: Maden Tetkik ve Arama Genel Müdürlüğü (MTA), Jeoloji Etüdleri Dairesi.

Beyaz Gazete. (2014, 09 25). Gaziantep'te Sel Felaketi Açılaması. Beyaz Gazete: http://beyazgazete.com/haber/2014/9/25/gaziantepte-sel-felaketi-aciklamasi-2380531.html adresinden alınd1

Bircan, D. (2014). 2013 Yılı Hatay Il Çevre Durum Raporu. Hatay: T. C. Çevre ve Şehircilik Bakanlığı.

Bodur, A. (2018). Sel ve İstanbul: Sel Riskine Karşı Yapılan Dere Islah Çalışmaları ile İlgili Bir Değerlendirme. Resilience (Dirençlilik) Dergisi, 2(1), 57-68.

Brandolini, P. Cappadonia, C., Luberti, G. M., Donadio, C., Stamatopoulos, L. Maggio, C. D., Faccini, F., Stanislao, C., Vergari, F., Paliaga, G., Agnesi, V., Alevizos, G., Monte, M. D. (2019). Geomorphology of the Anthropocene in Mediterranean urban areas. Progress in Physical Geography, 1-34.
Canpolat, E. (2014). Gölcük (Isparta) Volkanizması ve Volkanik Gaz Risk Analizi. İstanbul: İstanbul Üniversitesi Yayınlanmamış Doktora Tezi.

Crowards, T. (2000). Comparative Vulnerabilitiy to Natural Disasters in the Caribbean. OAS/USDE-NOAA/CSCW Workshop on Vulnerability Assessment Techniques. Charleston, South Carolina, March 20-22: Caribbean Development Bank Staff Working Paper No.1/00.

Cumhurbaşkanlığı Devlet Arşivleri Başkanlığ 1 Cumhuriyet Arşivleri

Dölek İ. (2013). Muş’ta yaşanan sel ve taşkınlara neden olan doğal faktörlerin analizi. Marmara Coğrafya Dergisi, 28, s. 408-422.

DSİ 6. Bölge Müdürlüğü Havza Yönetimi, İzleme ve Tahsisler Şube Müdürlüğü. (2016). Hatay-Erzin İçmeler “24.09.2014 Taşkını” ve “Taşkına Maruz Alan İlanı”. 4. Ulusal Taşkın Sempozyumu. Rize: http://www.dsi.gov.tr/docs/sempozyumlar/24-erzin-i\%C3\%A7 meler-ta $\%$ C5 $\% 9$ Fk $\%$ C4\%B1 na-maruz-alan-ilan $\%$ C4\%B1-(c-k\% C4\%B11\%C4\%B1\%C3\%A7aslan)AAF164B146E1.pdf?sfvrsn=2.

Elbaşı, E. \& Özdemir, H. (2018). Marmara denizi akarsu havzalarının morfometrik analizi. Coğrafya Dergisi-Journal of Geography 36, 63-84.

Emekli, G. (2001). Doğal felaketler ve turizm: İzmir örneği. 2. Ulusal Turizm Sempozyumu Bildiri Kitabı (s. 199-216). Türkiye Turizmini Araştırma Enstitüsü.

Ergünay, O. (2007). Türkiye'nin Afet Profili. TMMOB Afet Sempozyumu, (s. 14). Ankara.

Ertek, T. A. (2016). İnsan Faaliyetlerine Bağlı Jeomorfokronolojik Y1kımlar. TUCAUM Uluslararası Coğrafya Sempozyumu (13-14 Ekim 2016) , (s. 201-2019). Ankara.

Ertek, T. A. (2017). Antropojenik Jeomorfoloji: Konusu, Kökeni ve Amac1. Türk Coğrafya Dergisi, 69-79.

Fural, Ş, Cürebal, Ş. \& İnan, F. (2019). Elmalı'da (Antalya) Yağışın Tetiklediği Sel, Taşkın ve Çamur Akıntısı Afetlerinin Jeomorfolojik Analizi. Jeomorfolojik Araştırmalar Dergisi, 3, s. 49-61.

Gökçe, O. Özden, Ş. \& Demir, A. (2008). Türkiye'de Afetlerin Mekansal ve Istatistiksel Dă̆llımı. Afet Bilgileri Envanteri. Ankara.: Bayındırlık ve İskan Bakanlığı, Afet İşleri Genel Müdürlüğü, Afet Etüt ve Hasar Tespit Daire Başkanlığı.

Gregory, K. \& Walling, D. (1968). The variation of drainage density within a catchment. International Association of Scientific Hydrology. Bulletin, 69-84.

Gülbahar, N. (24-26 Ekim 2013). Türkiye'de oluşan taşkınların nedenleri ve etkilerinin azaltılması üzerine bir çalışma. Taşkın ve Heyelan Sempozyumu, (s. 533-542). Trabzon.

Hatay Valiliği, Hatay Kültür Envanterleri (2014), Cilt II, s.220

Hatay Valiliği İl Afet ve Acil Durum Müdürlüğü.

Holben, B. \& Fraser, R. (1984). Red and near infrared response to off nadir viewing. International Journal of Remote Sensing, 5, 145-160.

Kadıŏlu, Y, Bağc1, H. \& Yılmaz, C. (2016). Doğu Karadeniz kiyı kuşağındaki doğal afetlere bir örnek: 21 Eylül 2016 tarihli Beşikdüzü seli ve heyelanları. Marmara Coğrafya Dergisi, 36, 232-242. 
Karakuyu, M. (2002). Şehirleşmenin küresel iklim sapmaları ve taşkınlar üzerindeki etkisi. Marmara Coğrafya Dergisi, 6, 97-108.

Karataş, A. (2019). Ofiyolit hidrografyası ve hidrojeolojisi. İstanbul: Çantay Kitabevi.

Kelkit, A. (1992). Sağlık turizmi yönünden Erzin içmelerinin çevre düzenleme ilkeleri. Çukurova Üni. Fen Bilimleri Enstitüsü, Yayımlanmamış Yüksek Lisans Tezi, Adana.

Kuzucuğlu, C. Çiner, A. \& Kazancı, N. (2019). The geomorphological regions of Turkey. C. Kuzucuğlu, A. Çiner, \& N. Kazancı içinde, Landscapes and Landforms of Turkey (s. 41-180). Cham, Switzerland: Springer.

Melesse, A. M., Jordan, J. D. (2003). Spatially Distributed Watershed Mapping and Modelling: Thermal Maps and Vegetation Indices to Enhance Land Cover and Surface Microclimate Mapping: Part 1. Journal of Spatial Hydrology Volume 3 No 2.

Mülazımoğlu, N. S. (1979). İskenderun Körfezi Tabanı, Kıyıları ve Çevresinin Kuvaterner Jeolojisi ve Jeomorfolojisi (Yayımlanmamış Doktora Tezi). İstanbul: İstanbul Üniversitesi Coğrafya Enstitüsü Strüktür ve Yeraltı Kaynakları Kürsüsü.

MGM. (2020, 05 15). Tarım ve Orman Bakanliğı Meteoroloji Genel Müdürlüğ̈̈. Maksimum Yağışlar Şiddet ve Tekerrür Analizleri: https://www.mgm.gov.tr/veridegerlendirme/maksimum-yagislar. aspx

Noori, N. K., Kalın, L., Şen, S., Sarivastava, P., Lebleu, C. (2016). Identifying areas sensitive to land use/land cover change for downstream flooding in a coastal Alabama watershed. Regional Environmental Change, 16(6), 1833-1845.

Onuşluel, G. \& Harmancioğlu, N. (2002). Su kaynaklı doğal afet: Taşkın. Türkiye Mühendisleri Haberleri, Sayl: 420-421-422.

Özdemir, H. (2007). Havran çayı havzasının (Balıkesir) CBS ve uzaktan aygılama yöntemleriyle taşkın ve heyelan risk analizi. İstanbul: İstanbul Üniversitesi Sosyal Bilimler Enstitüsü Coğrafya Anabilim Dalı (Basılmamış Doktora Tezi).

Sarıgül, O. Turoğlu, H. (2020). Kahramanmaraş Şehri Sel ve Taşkınlarının Coğrafi Analizi ve Öngörüler. Coğrafya Dergisi, 40, 275-293.

Schults, G. A., Engman, G. T. (2000). Remote Sensing in Hydrology and Water Management,. Springer-Verlag, Berlin.

Schumm, S. (1956). Evolution of drainage systems and slopes in badlands at Perth Amboy. New Jersey. Geol. Soc. Am. Bull. 67, 597646.
Sellers, P. (1985). Canopy reflectance, photosynthesis and transpiration. Int. J. Remote Sensing, 6, 1335-1372.

Sotomayor, A. (2002). A Spatial Analysis of Different Forest Cover Types Using GIS and Remote Sensing Techniques; A Case study in Shivapuri Area, Nepal,. Master of Science Thesis, ITC, Netherland.

Stein, A. Draxler, R. Rolph, G. \& Stunder, B. (2020, 03 10). Atmospheric transport and dispersion modeling system, Bull. Amer. Meteor. Soc., 96, 2059-2077,. NOAA Air Resources Laboratory, HYSPLIT Trajectories, : https://www.ready.noaa.gov/HYSPLIT_traj.php adresinden alınd

Strahler, A. (1952). Hypsometric analysis of erosional topography. Bulletin of the Geological Society of America, 63, pp 1117-1142.

Strahler, A. N. (1958). Dimensional analysis applied to vially eroded landforms. Geological Society of America Bulletin 69, 279-299.

Sunkar, M. \& Tombul, S. (2011). Effects of changes in geomorphological units on flood and torrent events due to rapid urbanization in Batman. e-Journal of New World Sciences Academy, Volume: 6, Number: 1, Article Number: $4 A 0034$.

Şahin İ. F. (2007). Sağlık turizmi açısından Erzin içmeleri ve çevresel etkileri. Çeşme Ulusal Turizm Sempozyumu Bildiriler Kitabı (21-23 Kasim 2007), s. 393-401, İZMIR.

Turoğlu, H. (2011). İstanbul'da Meydana Gelen Sel ve Taşkınlar. Fiziki Coğrafya Araştırmaları; Sistematik ve Bölgesel, Türk Coğrafya Kurumu Yayınları, No:5, , 411-430.

Turoğlu, H. Erginal, A. E. Cürebal, İ. \& Döker, M. F. (2015). Hopa'da yağışın tetiklediği sel, taşkın ve heyelan afetleri. III. Ulusal Jeomorfoloji Sempozyumu, Samsun, s. 553-557.

Web 1. (2019, 08 25). NASA Earth Data. ASF Data Seach Vertex: https://search.asf.alaska.edu/\#/ adresinden alındı

Weissel, J. K. Pratson, L. F., Malinverno, A. (1994). The length-scaling properties of topography. Journal of Geophysical Research, 99, 13997-14012.

Yalçın, H. Meriç, E. Avşar N. Bozkaya, Ö. \& Barut İ. F. (2004). "İskenderun körfezi güncel foraminiferlerinde gözlenen jeokimyasal anomaliler. Türkiye Jeoloji Bülteni, 47, 2, Ağustos 2004.

Yılmaz, C. \& Kaya, M. (2018). Oluşum sebepleri, verdiği zararlar ve alınan önlemler bağlamında Samsun-Atakum Sel ve Taşkınları. TÜCAUM 30. Yıl Uluslararası Coğrafya Sempozyumu, ANKARA. 